\title{
A CONSTRUÇÃO SÓCIO-POLÍTICA DA EJA NA CIDADE DE PONTA GROSSA: um olhar frente a realidade discente
}

\author{
Rita de Cássia Oliveira ${ }^{\mathrm{i}}$ \\ Paola Andressa Scortegagnaii \\ Flávia da Silva Oliveiraii
}

\section{RESUMO:}

No contexto da pós-modernidade, a educação insere-se como um poderoso instrumento de avanço social. Neste trabalho realizou-se uma reflexão sobre a EJA no Brasil. A pesquisa teve como objetivos identificar as políticas públicas voltadas para EJA e o perfil dos alunos beneficiados por esta modalidade na cidade de Ponta Grossa/Paraná. A investigação foi descritiva, interpretativa, quanti-qualitativa. Na pesquisa de campo utilizou-se questionário aos alunos como instrumento de coleta de dados. Percebeu-se que a EJA constitui uma modalidade de educação cada vez mais reconhecida socialmente e considerada pelos alunos como possibilidade de resgate da cidadania e ascensão social e profissional.

Palavras-chave: Políticas Públicas, Educação de Jovens e Adultos, Educação Permanente.

\section{BUILDING SOCIAL POLICY OF EJA IN CITY OF PONTA GROSSA: a look at the reality facing students}

\begin{abstract}
:
In the post-modernity context, education must be seen as a powerful instrument of social advancement. In this work there was a reflection on the EJA in Brazil. The research aimed to identify the public policies for EJA and profile of students benefit from this mode in the city of Ponta Grossa / Paraná. The research was descriptive, interpretative, quantitativequalitative. In field research used a questionnaire to students as a tool for data collection. It was noticed that the EJA is a form of education increasingly socially recognized and considered by students as a possibility for recovery of citizenship and social and professional growth.
\end{abstract}

Key-words: Public Policy, Young and Adults Education, Permanent Education.

\section{INTRODUÇÃO}

Nos últimos anos no Brasil vem ocorrendo mudanças econômicas, culturais, políticas e sociais e em decorrência delas a população se depara com diferentes desafios que impulsionam crescimento num compasso acelerado. Sabe-se que a educação constitui um processo presente nas diferentes sociedades, assumindo configurações, ideais e objetivos distintos conforme o lugar e o tempo histórico.

A educação por meio de sua origem, seus objetivos e sua função constitui-se como um fenômeno social e guarda relações como o contexto político, econômico, científico e cultural de uma sociedade historicamente determinada.

É necessário, contudo, compreender que a educação é um conjunto da produção humana, e se caracteriza como um trabalho não-material, tendo relação direta com hábitos, conceitos, habilidades, atitudes e idéias (SAVIANI, 2003). 
Embora seja um processo constante em todas as sociedades, a educação não é a mesma em todos os tempos e lugares, se vincula ao projeto de homem e de sociedade que se deseja emergir através do processo educativo. O fenômeno educativo só pode ser entendido como uma prática social, que envolve uma multiplicidade de aspectos, os quais permeiam a vida total do homem. Dessa maneira, "a educação é o processo pelo qual a sociedade forma seus membros à sua imagem e em função de seus interesses" (PINTO, 1989, p.29).

A sociedade pós-moderna valoriza muito o conhecimento adquirido pelos indivíduos e, para acompanhar as transformações no mundo do trabalho, torna-se necessária uma maior qualificação profissional. Nessa perspectiva, a educação assume cada vez mais relevância e passa a ser reclamada por uma parcela maior da população como imprescindível para a integração e participação social.

Ao se pensar nesta participação social, percebe-se que a identidade de jovens e adultos vincula-se diretamente à sua atividade laboral, e esta por sua vez define papéis sociais e a representatividade de cada indivíduo na sociedade.

O segmento dos jovens e adultos distingue-se dos demais segmentos da educação formal, sendo necessário uma re-avaliação de uma modalidade de ensino que supra as necessidades educacionais que esse grupo carece, através de uma relação entre formação e mercado de trabalho. Pois, a realidade educacional brasileira é um exemplo acabado de contradição entre a declaração dos direitos e a prática social. Existe um descompasso entre os processos de interação entre estudo e trabalho (PICONEZ, 2002).

A educação voltada para jovens e adultos, que estão em atividade, como trabalhadores, se coloca como uma das mais estratégicas formulações para a possível transformação e, no limite, revolução da sociedade injusta, discriminatória e elitista em que vivemos (GADOTTI; ROMÃO, 2005).

A EJA justifica-se em grande medida como educação permanente, em virtude da crescente globalização da produção e dos mercados, da acelerada mudança tecnológica, dos crescentes desajustes do mercado de trabalho e da eventual redução da demanda por habilidades.

Educação permanente, segundo Pierre Furter (1976), não pode ser reduzida a uma simples educação extra-escolar, nem complementar, nem de adultos ou prolongada. Mas abre novas perspectivas no campo educacional, preconizando uma reestruturação e redefinição das estruturas vigentes no que diz respeito à educação de qualquer país.

Assim, a educação representa a possibilidade de mudança para essa classe, por muitas vezes excluída da sociedade. A EJA no Brasil vem ao encontro de algumas problemáticas sociais, porém é preciso perceber suas dificuldades e limitações.

$\mathrm{O}$ presente artigo resulta de uma investigação que objetivou identificar o perfil e as condições dos alunos da modalidade de EJA de Ponta Grossa, para que através desta, oferecer alternativas na área educacional para elaboração de políticas públicas educacionais para EJA, como também resgatar a cidadania e inserção social de jovens e adultos por meio desta modalidade.

\section{IDENTIDADE DA EJA E POLÍTICAS PÚBLICAS}

A EJA configura-se num âmbito ambíguo e muitas vezes contraditório, demonstrando a necessidade de uma organização, na qual a população beneficiada com esse segmento educacional realmente atinja seus objetivos enquanto cidadãos em busca de novas oportunidades através da educação. 
Esse segmento de ensino confronta-se com a diminuição das elevadas taxas de analfabetismo existentes no Brasil. Segundo o Índice Nacional de Analfabetismo Funcional (INAF/2007), 32\% da população entre 15 e 65 anos são considerados analfabetos funcionais, este índice era de $39 \%$ em 2001. Apesar do decréscimo significativo nos últimos anos, principalmente da população jovem, ainda está longe de se alcançar um índice aceitável de analfabetos, cumprindo assim, os objetivos educacionais traçados pela Organização das Nações Unidas (UNESCO), para 2015.

Em relação à EJA, destinada àqueles que não tiveram acesso ao ensino fundamental e ao médio na idade própria, segundo o Censo Escolar de 2008, no Brasil há 4.157.882 alunos nesta modalidade, em cursos presenciais com avaliação no processo, no ensino fundamental e médio (MEC/INEP).

Apesar dos dados apresentados representarem um importante avanço quanto à quantidade de alunos matriculados em cursos presenciais, a realidade vivenciada aponta que a alfabetização e a EJA apresenta-se no governo como uma proposta relegada a um segundo plano, por meio de um caráter apenas qualitativo.

“O Brasil é mais do que um país. É uma imensa região marcada por profundas assimetrias e desigualdades econômicas e sociais, regionais e étnicas, com um considerável e histórico atraso na construção da escola para todos" (TEODORO, 2003, p. 138).

O Estado, referenciando o estado máximo do lucro, estabelece em suas estruturas poucas ou quase incipientes condições de acesso a uma educação de qualidade, principalmente para a população mais pobre, dando cada vez mais ênfase, a um estado mínimo das condições básicas apenas como sobrevivência.

Nas sociedades capitalistas, a educação tem estado a serviço da manutenção dos privilégios de classe. A ideologia liberal, que dá sustentação ao sistema capitalista coloca a questão em termos de diferenças individuais, atribuindo ao próprio indivíduo o seu sucesso ou fracasso social e escolar, omitindo os condicionantes de ordem social, histórica, política e econômica que levam algumas pessoas ao sucesso e outras à marginalização ou exclusão do sistema como um todo, legitimando a sociedade de classes.

É possível perceber que a escola tem contribuído para reforçar situações de preconceito em relação às camadas pobres quando afirma que a educação trabalha apenas em nível das idéias e segue orientações e normas iguais para todos os alunos. Baseada em princípios individualizantes, acaba por rotular os indivíduos segundo seu aproveitamento, sem levar e, conta as condições concretas de existência e o universo cultural dos alunos.

Os teóricos crítico-reprodutivistas (Bourdieu, Passeron, Althusser, 1970), criticam a escola de inspiração liberal, denunciam seu caráter classista e os mecanismos utilizados para perpetuar as desigualdades sociais.

A escola não distribui poder, mas constrói saber que é poder. Não se muda a história sem conhecimentos, mas tem-se que educar o conhecimento para que se possa interferir no mercado como sujeitos, não como objeto. O papel da escola consiste em colocar o conhecimento nas mãos dos excluídos de forma crítica, porque, a pobreza política produz pobreza econômica (GADOTTI, 1997).

A educação desponta como um instrumento indispensável para a formação deste novo homem e novo profissional, através do processo de socialização e integração, sendo possível desmistificar os choques culturais e sociais presentes em nossa sociedade. Assim, a população passa a exigir cada vez mais condições de acesso e permanência na escola, com uma educação de qualidade, proporcionando uma formação que contemple as necessidades e aspirações. 
Todavia, a EJA no Brasil, configura-se cada vez mais como necessidade para a população não-escolarizada, que busca através da educação, superar suas mazelas sociais, sendo capaz de emergir no processo de qualificação tanto profissional quanto pessoal.

Essa modalidade vem ao encontro das classes sociais menos favorecidas, uma vez que o estado capitalista busca incessantemente o lucro exacerbado, sem preocupar-se com toda parcela da população que se encontra à margem desse contexto. Nestas condições, a educação apresenta-se como possibilidade de mudança a essa realidade vivenciada.

A EJA, no transcorrer do seu processo histórico, apresenta-se como uma educação compensatória (GADOTTI; ROMÃO, 2005), sendo vista como uma oportunidade para superar uma falha no processo educacional dos alunos inclusos nessa modalidade. Desta maneira, os beneficiados com a mesma, buscam na educação as possibilidades de superar suas condições de trabalho e sobrevivência.

Desta maneira, a implementação de políticas públicas voltadas para esta população torna-se indispensável, propiciando condições mínimas de sobrevivência, trabalho, além de estruturar uma educação de qualidade, que venha ao encontro dos objetivos desse segmento.

As políticas públicas fazem correspondência às orientações e disposições do governo, através das mais diversas decisões nas esferas sociais, influenciando a população direta ou indiretamente, nos âmbitos pessoais, profissionais, sociais e também educacionais. Estabelecem-se leis, diretrizes, planos, resoluções, estatutos e demais decisões provenientes do poder público.

As Políticas Públicas para a EJA configuram-se num espaço diferenciado de compensação, apesar de existirem muitas iniciativas em prol da disseminação da educação para todas as pessoas, como é previsto na própria Constituição Federal, no Artigo 205, que prescreve a educação como direito de todos e dever do estado. Este compromisso também foi reforçado na Declaração de Jomtien da Educação para Todos.

Segundo a Declaração de Jomtien, da qual o Brasil é signatário:

A educação é um direito fundamental de todos, mulheres e homens, de todas as idades, no mundo inteiro. Cada pessoa (criança, jovem ou adulto), deve estar em condições de aproveitar as oportunidades educativas voltadas para satisfazer suas necessidades básicas de aprendizagem.

Desta maneira, no contexto da EJA, "as políticas representam o espaço onde se manifesta a 'politicidade inerente à educação', na medida em que traduzem expectativas de ruptura ou de continuidade (VIEIRA, 2007, p. 56)".

Outra legislação vigente é a Lei de Diretrizes e Bases (Lei 9394/96), que apresenta a modalidade da EJA dentro da Educação Básica. No artigo 37, destaca-se que: "a educação de jovens e adultos será destinada àqueles que não tiveram acesso ou continuidade de estudos no ensino fundamental e médio na idade própria”. Desta maneira, o jovem ou adulto que não teve condições de inserir-se ou permanecer na educação formal, tem direito a essa educação.

Esta mesma lei apresenta no inciso $1^{\circ}$ do artigo 37 ,

$\S 1^{\circ}$ Os sistemas de ensino assegurarão gratuitamente aos jovens e aos adultos, que não puderam efetuar os estudos na idade regular, oportunidades educacionais apropriadas, consideradas as características do alunado, seus interesses, condições de vida e de trabalho, mediante cursos e exames. 
Desta maneira, estes alunos têm direito a uma educação gratuita que lhes assegure condições educacionais que sejam apropriadas às suas realidades, tanto nas condições pessoais, quanto profissionais.

Também em referência a EJA, destacam-se as Diretrizes Curriculares Nacionais para a EJA (Resolução CNE/CEB No 1 , de 5 de julho de 2000).

Parágrafo único. Como modalidade destas etapas da Educação Básica, a identidade própria da Educação de Jovens e Adultos considerará as situações, os perfis dos estudantes, as faixas etárias e se pautará pelos princípios de eqüidade, diferença e proporcionalidade na apropriação e contextualização das diretrizes curriculares nacionais e na proposição de um modelo pedagógico próprio, de modo a assegurar:

I - quanto à eqüidade, a distribuição específica dos componentes curriculares a fim de propiciar um patamar igualitário de formação e restabelecer a igualdade de direitos e de oportunidades face ao direito à educação;

II- quanto à diferença, a identificação e o reconhecimento da alteridade própria e inseparável dos jovens e dos adultos em seu processo formativo, da valorização do mérito de cada qual e do desenvolvimento de seus conhecimentos e valores;

III - quanto à proporcionalidade, a disposição e alocação adequadas dos componentes curriculares face às necessidades próprias da Educação de Jovens e Adultos com espaços e tempos nos quais as práticas pedagógicas assegurem aos seus estudantes identidade formativa comum aos demais participantes da escolarização básica.

Essas diretrizes salientam a importância da identidade da EJA, sendo uma modalidade própria da Educação Básica, considerando a realidade de seus alunos, apresentando uma formação que contemple as necessidades de ensino e aprendizagem destes. Também, através destas diretrizes fica assegurado o direito a igualdade e oportunidades de acesso e permanência à educação.

Para Arroyo, "a história mostra que o direito à educação somente é reconhecido na medida em que vão acontecendo avanços sociais e políticos na legitimação da totalidade dos direitos humanos". Assim, "a re-configuração da EJA estará atrelada a essa legitimação" (2006, p. 28).

Esses sujeitos, por muitas vezes, encontram-se a margem do processo educacional, pois em sua realidade foram submetidos ao mercado de trabalho ou não encontraram condições de manterem-se na escola. É necessário, "vê-los como alunos, tomarmos consciência de que estão privados dos bens simbólicos que a escolarização deveria garantir (p. 23)". É preciso superar a idéia de que a EJA seja vista como política de continuidade na escolarização, propiciando uma segunda oportunidade para os jovens e adultos que não tiveram acesso à escola (ARROYO, 2006).

Segundo Porto (2004), as políticas públicas têm sido insuficientes para atender ao direito de todos os brasileiros à educação e, embora sejam ampliadas as ofertas, elas continuam excluindo elevado número de jovens e adultos de tais oportunidades, quer pelo não-acesso, quer pela não-permanência.

Em outros contextos, também se pode destacar a ausência de espaços escolares adequados, para suprir a demanda. Pode-se também citar a própria falta de interesse de 
alguns alunos no período de escolarização, que os remeteu a busca da escola, por melhoria nas condições pessoais, sociais, financeiras e relacionadas à ascensão no trabalho.

A EJA estabelece-se como uma modalidade de ensino, que apesar dos conflitos referentes a sua organização, possui um caráter de educação permanente, pois a educação é um processo e tem um fim. Além deste ponto, também se percebe que esta modalidade atinge um segmento diferenciado, o qual possui suas especificidades peculiares e necessita de uma percepção diferenciada acerca da educação formal. "Ao reconhecer que a educação se faz ao longo da vida, torna-se indispensável intensificar o movimento sóciopolítico de universalizá-la" (PORTO, 2003, p. 33)

A educação problematizadora se identifica com o movimento permanente onde se encontram os sujeitos, que são inconclusos; partindo dos mesmos, esse movimento é histórico, onde esse sujeito é objeto (FREIRE, 2005).

Por muitas vezes, a EJA, considera-se como um segmento de segunda linha, ou seja, supre as dificuldades de um contingente desfavorecido. Assim, ocorre em muitos casos um choque cultural, pois, considera-se que o sujeito que constitui a EJA, é um individuo sem cultura ou por vezes incapaz de atingir suas metas através da educação.

Para Santos (2003, p. 74),

os jovens e adultos pouco escolarizados trazem consigo um sentimento de inferioridade, marcas de fracasso escolar, como resultado de reprovações, do não-aprender. A não-aprendizagem, em muitos casos, decorreu de um ato de violência, porque o aluno não atendeu às expectativas da escola. Muitos foram excluídos da escola pela evasão (outro reflexo do poder da escola, do poder social); outros a deixaram em razão do trabalho infantil precoce, na luta pela sobrevivência (também vítimas do poder econômico).

Torna-se significativo referenciar a educação de adultos no contexto das políticas sociais, remetendo às exigências educativas que a sociedade impõe no âmbito político.

Segundo Freire (2005), ao ligar-se a uma das tendências da moderna concepção progressista, admite que seja necessário tornar a educação acessível às camadas populares. Porém, a educação cumprirá caráter político e social na medida em que possa criar o espaço de discussão e problematização da realidade, com vistas à educação consciente, voltada para o exercício da cidadania por sujeitos comprometidos com a transformação da realidade, envolvendo jovens, adultos e idosos nas mais diversas dimensões.

Um regime político democrático exige que as pessoas tenham domínio de instrumentos da cultura letrada, que assumam valores e atitudes democráticas: a consciência de direitos e deveres, a disposição para a participação, para o debate de idéias e o reconhecimento de posições diferentes das suas.

O Brasil vem reconstruindo as instituições democráticas e nesse processo a educação tem um papel a cumprir com relação à consolidação da democracia em nosso país.

Assim, cabe a educação estabelecer uma relação democrática entre a política e os sujeitos deste paradoxo educacional, a fim de re-ordenar e reconstruir gradativamente um processo ensino-aprendizagem pautado na construção e re-construção crítica, reflexiva e democrática dos conhecimentos, onde todos os indivíduos presentes neste meio possam desenvolver-se e constituírem-se como cidadãos atuantes e conscientes. 


\section{A EJA NA CIDADE DE PONTA GROSSA}

A modalidade da EJA na cidade de Ponta Grossa configura-se como um espaço em construção, apesar de já há alguns anos fazer parte do contexto educacional da cidade, principalmente a partir dos anos 1990. Porém, esta modalidade é muitas vezes considerada aquém da Educação Básica.

Para a realização desta pesquisa, foram visitadas nos anos de 2007 e 2008, 11 escolas da rede municipal que ofertam a modalidade da EJA, desde as Séries Iniciais do Ensino Fundamental, até o Ensino Médio. Estas escolas foram delimitadas, através de 4 quadrantes, sendo que em 3 quadrantes foram selecionadas 3 escolas e em 1 quadrante, 2 escolas. Esta seleção se deu pela demanda de alunos que a escola atende, localização e possibilidade de realizar a pesquisa, pois em algumas escolas não foi possível aplicar os questionários.

Foram obtidos 98 questionários de alunos. Alguns alunos não aceitaram responder o questionário, há um considerável número de evadidos e outros alunos não estavam presentes durante os dias em que houve a aplicação de questionários. Em algumas escolas, há mais de uma sala de EJA, porém para a realização da pesquisa, foi permitido acesso a apenas uma sala.

O perfil dos alunos da EJA em Ponta Grossa

Segundo o Censo Escolar 2008 (INEP/MEC), na cidade de Ponta Grossa na Rede Municipal de Ensino (urbana), há 730 alunos matriculados na EJA (presencial). Para realização desta pesquisa, foram aplicados questionários em 11 escolas em diferentes regiões da cidade. Obteve-se 98 questionários respondidos completamente, os quais foram utilizados para a análise de dados; os questionários não respondidos, foram desconsiderados.

Os alunos responderam questões sobre seu perfil pessoal, econômico, social e escolar. O questionário apresentou questões abertas e fechadas.

Com relação à idade, predominou 21 alunos (21,43\%) entre 25 a 30 anos; 20 alunos $(20,41 \%)$ com 31 a 35 anos; 19 alunos $(19,39 \%)$ com idade acima de 41 anos; 14 alunos $(14,29 \%)$ entre 15 a 19 anos; 13 alunos $(13,29 \%)$ com 20 a 24 anos e o menor número, 11 alunos $(11,22 \%)$ com 36 a 40 anos, conforme quadro e gráfico abaixo.

Quadro e gráfico1: Idade dos alunos

\begin{tabular}{|c|c|c|}
\hline Idade & Parcial & Porcentagem \\
\hline 15 a 19 anos & 14 & $14,29 \%$ \\
\hline 20 a 24 anos & 13 & $13,26 \%$ \\
\hline 25 a 30 anos & 21 & $21,43 \%$ \\
\hline 31 a 35 anos & 20 & $20,41 \%$ \\
\hline 36 a 40 anos & 11 & $11,22 \%$ \\
\hline Acima de 41 anos & 19 & $19,39 \%$ \\
\hline Total & 98 & $100 \%$ \\
\hline
\end{tabular}




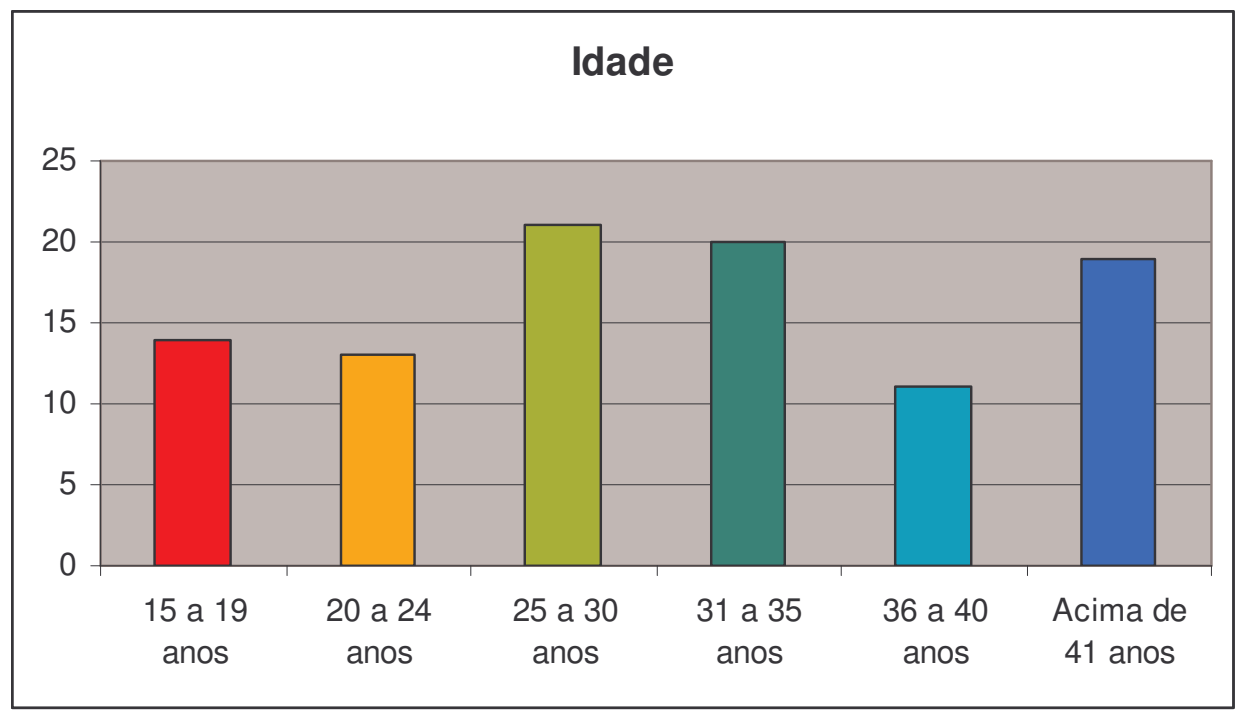

Fonte: dados obtidos através dos questionários.

Com relação ao sexo, o maior percentual de 60 alunos, representando 61,22\%, são do sexo feminino e o restante 38 alunos, representando 38,78\% do sexo masculino.

\section{Quadro e gráfico 2: Sexo}

\begin{tabular}{|c|c|c|}
\hline Sexo & Parcial & Porcentagem \\
\hline Masculino & 38 & $38,78 \%$ \\
\hline Feminino & 60 & $61,22 \%$ \\
\hline Total & 98 & $100 \%$ \\
\hline
\end{tabular}

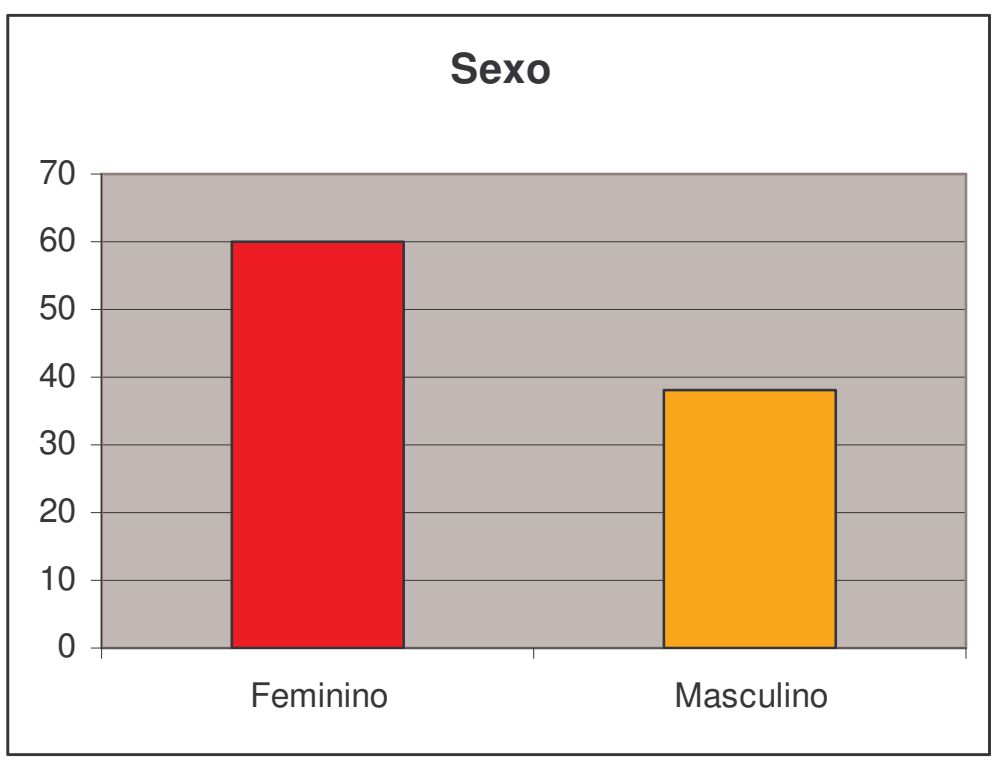

Fonte: dados obtidos através dos questionários.

Referente ao estado civil predominaram os casados, sendo 47 alunos $(47,96 \%)$, seguido dos solteiros 31 alunos (31,63\%). Em terceiro encontra-se 13 alunos $(13,27 \%)$ que moram com companheiro; 4 alunos (4,08\%) são separados, 2 alunos $(2,04 \%)$ são viúvos e 
apenas 1 alunos $(1,02 \%)$ é divorciado. Os dados podem ser visualizados no quadro e gráfico a seguir.

\section{Quadro e gráfico 3: Estado civil}

\begin{tabular}{|c|c|c|}
\hline Estado civil & Parcial & Porcentagem \\
\hline Solteiro & 31 & $31,63 \%$ \\
\hline Casado & 47 & $47,96 \%$ \\
\hline Separado & 4 & $4,08 \%$ \\
\hline Divorciado & 1 & $1,02 \%$ \\
\hline Viúvo & 2 & $2,04 \%$ \\
\hline Mora com companheiro & 13 & $13,27 \%$ \\
\hline Total & 98 & $100 \%$ \\
\hline
\end{tabular}

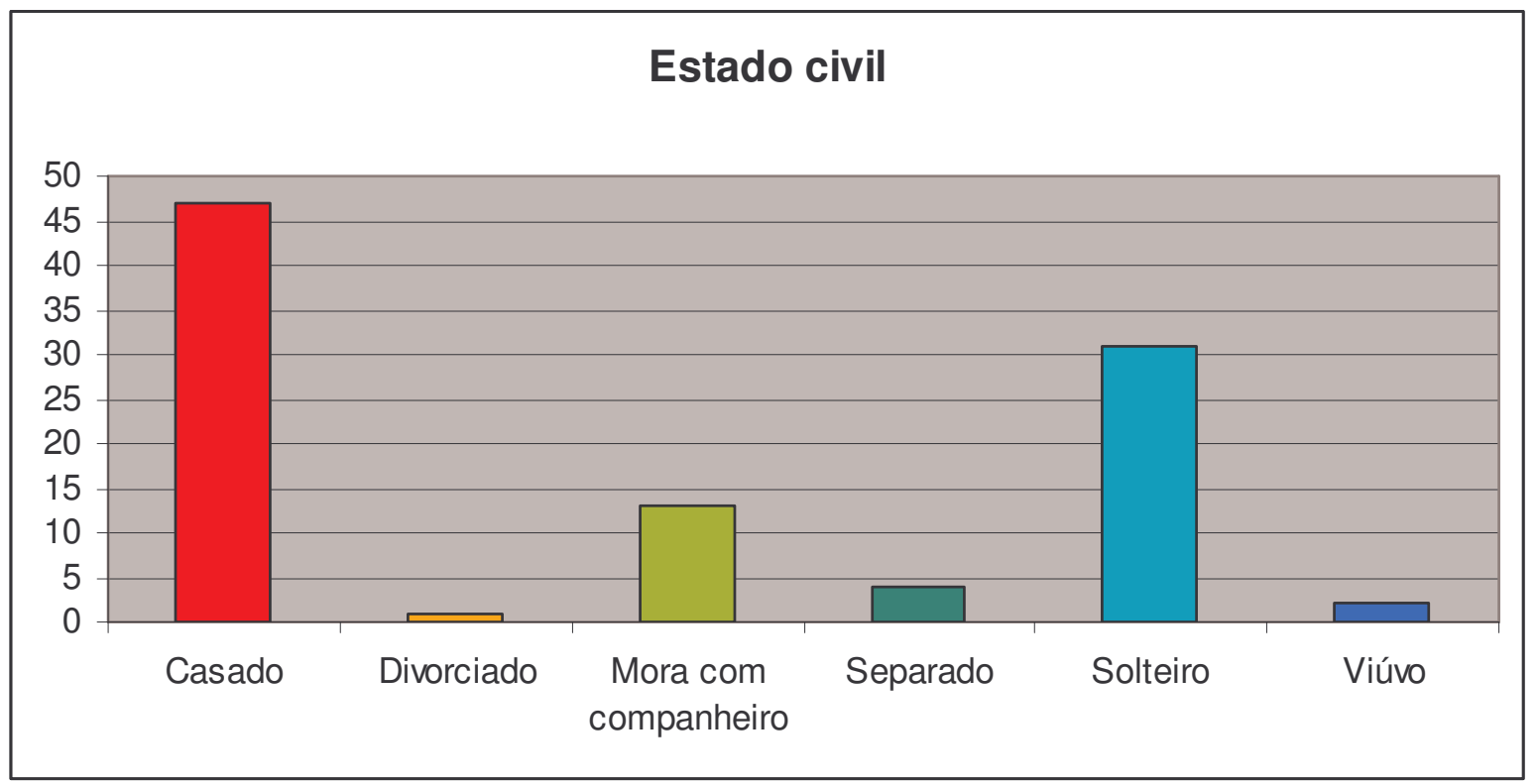

Fonte: dados obtidos através dos questionários.

Os alunos que participaram da pesquisa, quando questionados sobre o número de filhos, indicaram que $27(27,55 \%)$ não possuem filhos, 18 alunos $(18,37 \%)$ possuem apenas 1 filho; 17 (17,35\%) possuem 2 filhos; 16 (16,32\%) possuem 3 filhos, 15 alunos $(15,31 \%)$ possuem 5 ou mais filhos e o menor número de alunos, 5 possuem 4 filhos $(5,1 \%)$. Os dados estão apresentados nos quadros e no gráfico abaixo.

Quadro e gráfico 4: Possui filhos? Quantos?

\begin{tabular}{|c|c|c|}
\hline Filhos & Parcial & Porcentagem \\
\hline Não & 27 & $27,55 \%$ \\
\hline 1 filho & 18 & $18,37 \%$ \\
\hline 2 filhos & 17 & $17,35 \%$ \\
\hline 3 filhos & 16 & $16,32 \%$ \\
\hline 4 filhos & 5 & $5,1 \%$ \\
\hline 5 ou mais filhos & 15 & $15,31 \%$ \\
\hline (2) & 98 & $100 \%$ \\
\hline
\end{tabular}




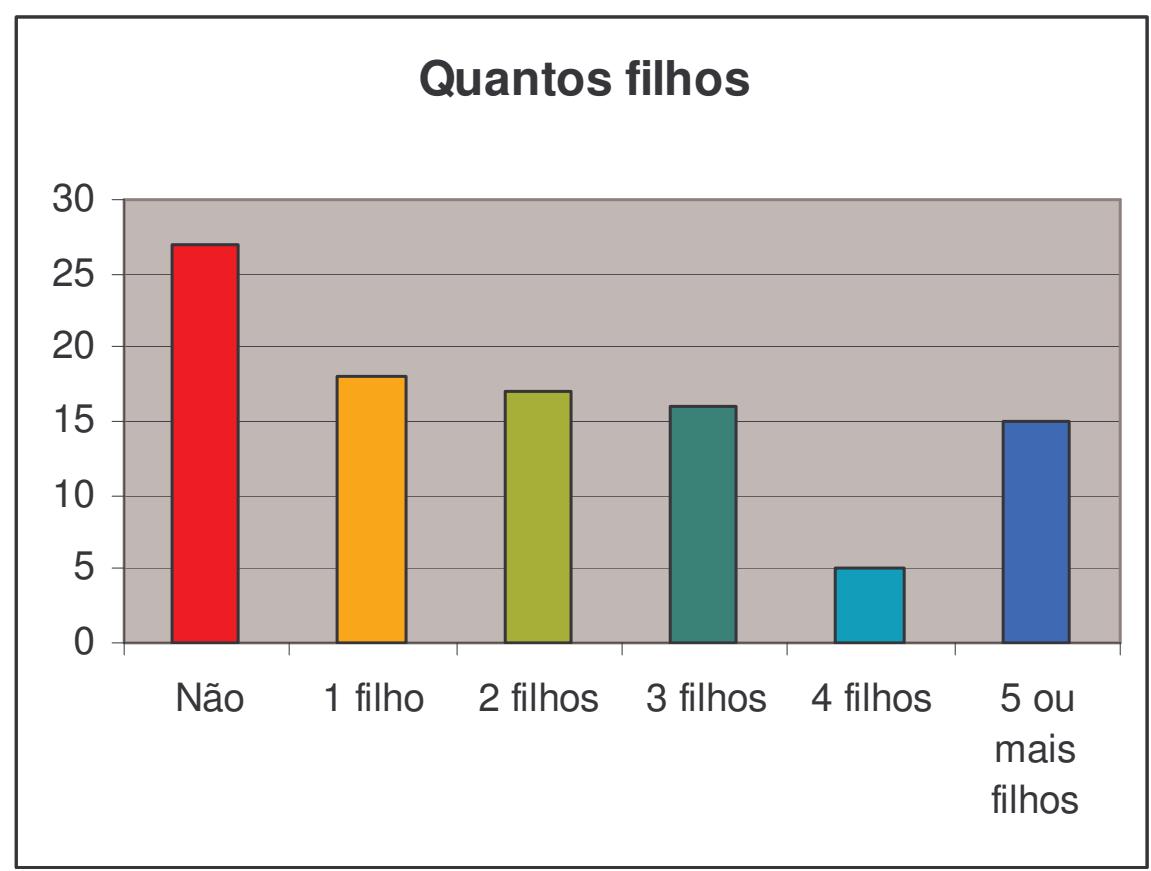

Fonte: dados obtidos através dos questionários.

Os alunos quando questionados sobre o que gostam de fazer nos seus momentos de folga ou de lazer, apresentaram atividades variadas, predominando as visitas à igreja indicadas por 49 alunos (50\%), visitar os parentes apontados por $44(44,9 \%)$ e assistir televisão escolhida por 39 alunos $(39,76 \%)$. As atividades menos indicadas foram: 10 alunos $(10,2 \%)$ escolheram freqüentar bares e lanchonetes; 5 alunos $(5,1 \%)$ optam por frequientar parques e praças e 3 alunos $(3,06 \%)$ preferem permanecer em casa, conforme quadro e gráfico abaixo.

\section{Quadro e gráfico 5: Atividades em momentos de folga ou lazer}

\begin{tabular}{|l|c|c|}
\hline \multicolumn{1}{|c|}{ Momentos de folga/lazer } & Parcial & Porcentagem \\
\hline Visitar parentes & 44 & $44,9 \%$ \\
\hline Ver televisão & 39 & $39,76 \%$ \\
\hline Visitar amigos & 20 & $20,41 \%$ \\
\hline Ir à igreja & 49 & $50 \%$ \\
\hline Freqüentar bares/lanchonetes & 10 & $10,2 \%$ \\
\hline Freqüentar parques/praças & 5 & $5,1 \%$ \\
\hline Outro: permanece em casa & 3 & $3,06 \%$ \\
\hline \multicolumn{1}{r|}{ Total } & 98 & $100 \%$ \\
\hline
\end{tabular}




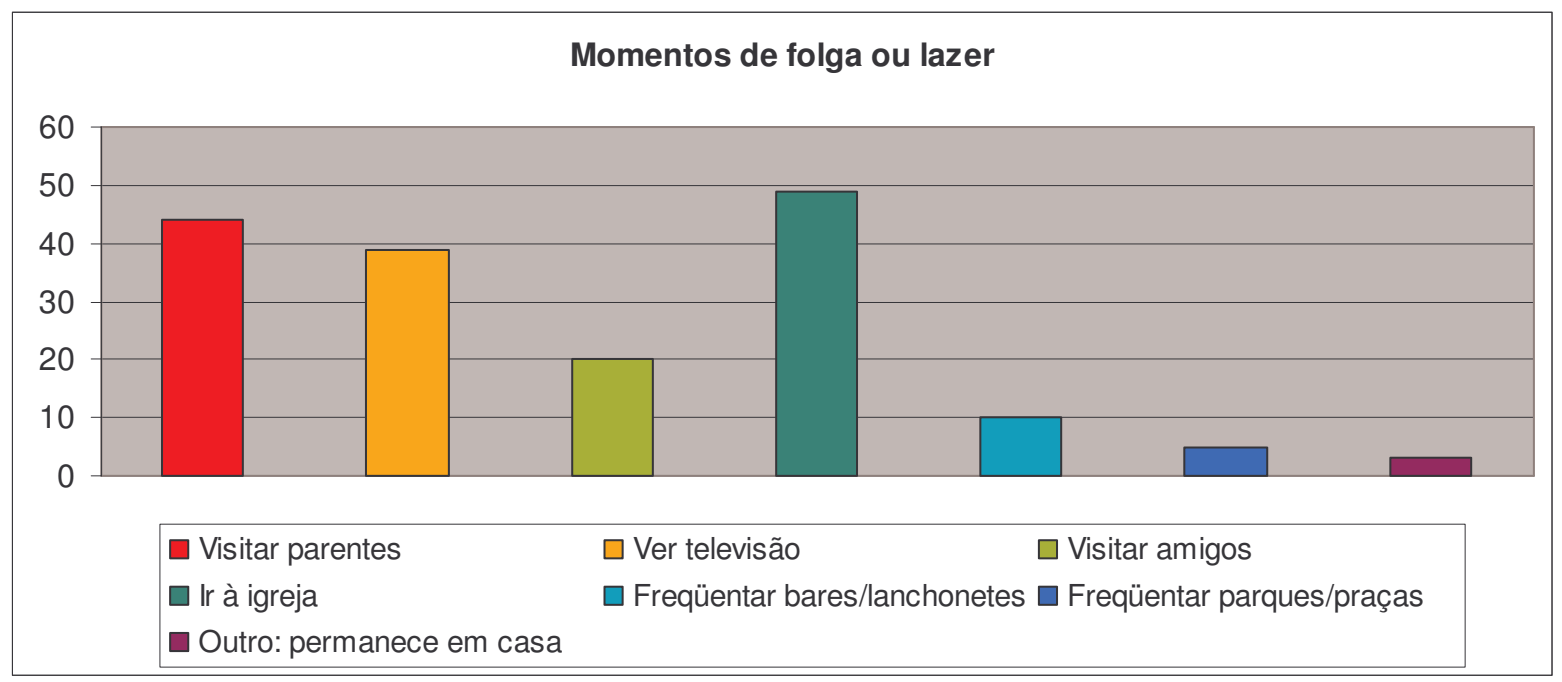

Fonte: dados obtidos através dos questionários.

Referente à atividade laboral dos alunos participantes da pesquisa, o maior número, 21 alunas $(21,44 \%)$ desenvolvem atividades no lar, seguidas de 13 alunas $(13,27 \%)$, que trabalham como empregada doméstica.

Como auxiliar de serviços gerais, operador de produção, pedreiro, vendedor, são representados por 5 alunos $(5,1 \%)$ em cada uma dessas atividades; e os demais alunos distribuídos em diferentes ocupações que estão explicitadas no quadro e gráfico abaixo.

\section{Quadro e gráfico 6: Ocupação (emprego)}

\begin{tabular}{|l|c|c|}
\hline \multicolumn{1}{|c|}{ Ocupação } & Parcial & Porcentagem \\
\hline Açougueiro & 1 & $1,02 \%$ \\
\hline Ajudante de pedreiro & 2 & $2,04 \%$ \\
\hline Aposentado & 2 & $2,04 \%$ \\
\hline Aux de serviços gerais & 5 & $5,1 \%$ \\
\hline Carpinteiro & 1 & $1,02 \%$ \\
\hline Chacareiro & 2 & $2,04 \%$ \\
\hline Do lar & 21 & $21,44 \%$ \\
\hline Empregada doméstica & 13 & $13,27 \%$ \\
\hline Encanador & 1 & $1,02 \%$ \\
\hline Estudante & 2 & $2,04 \%$ \\
\hline Leiteiro & 1 & $1,02 \%$ \\
\hline Mecânico & 2 & $2,04 \%$ \\
\hline Merendeira & 2 & $2,04 \%$ \\
\hline Metalúrgico & 1 & $1,02 \%$ \\
\hline Militar & 1 & $1,02 \%$ \\
\hline Não respondeu & 2 & $2,04 \%$ \\
\hline Operador de produção & 5 & $5,1 \%$ \\
\hline Pedreiro & 5 & $5,1 \%$ \\
\hline Pintor & 2 & $2,04 \%$ \\
\hline Vendedor & 5 & $5,1 \%$ \\
\hline Verdureiro & 1 & $1,02 \%$ \\
\hline Vigia & 2 & $2,04 \%$ \\
\hline Zeladora & 3 & $3,06 \%$ \\
\hline & 98 & $100 \%$ \\
\hline
\end{tabular}




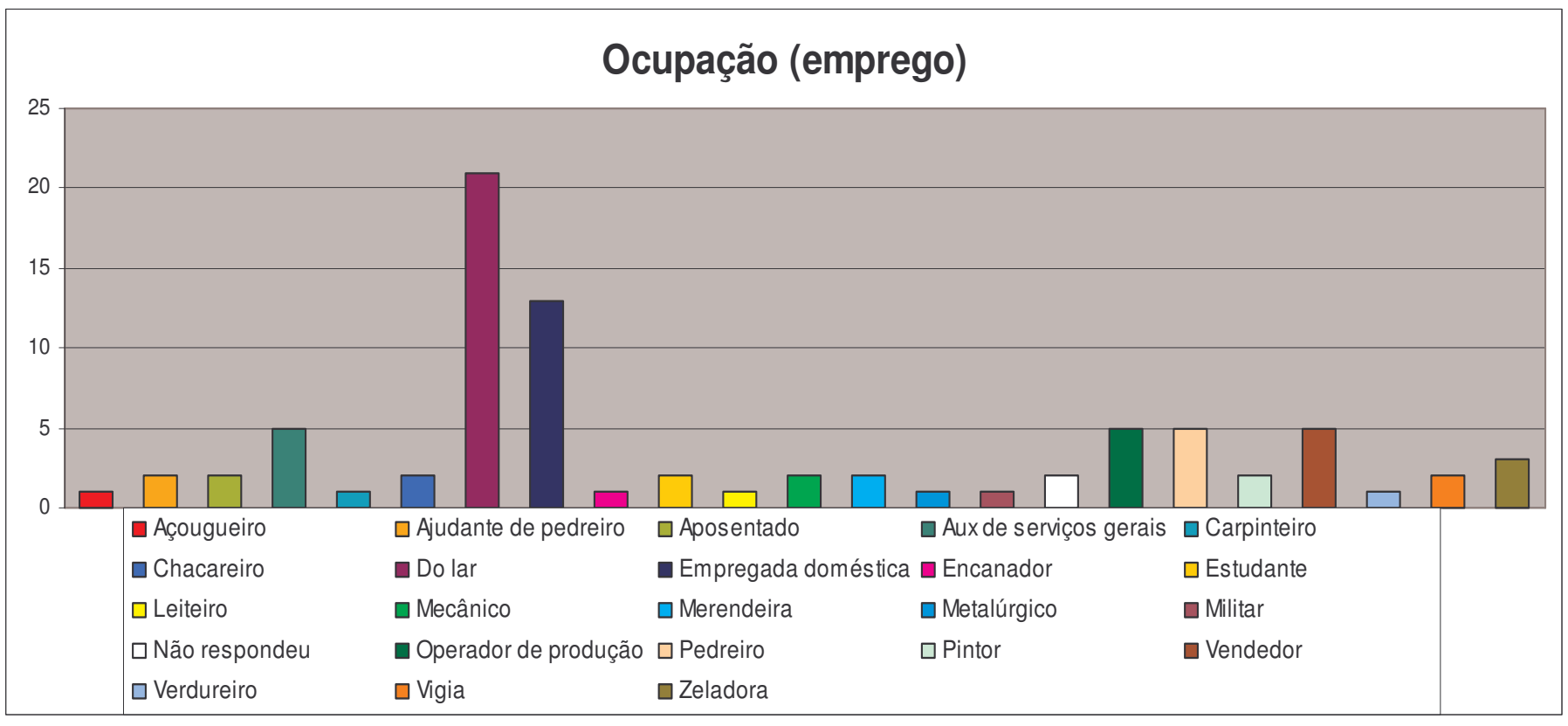

Fonte: dados obtidos através dos questionários.

O trabalho de 40 alunos (40,82\%) é formal, de 37 alunos (37,75\%) é informal e 7 alunos $(14,29 \%)$ são autônomos. Em número de 14 alunos (14,29\%) responderam outros, entre eles enquadram-se os desempregados.

\section{Quadro e gráfico 7: Trabalho}

\begin{tabular}{|c|c|c|}
\hline Trabalho & Parcial & Porcentagem \\
\hline Formal & 40 & $40,82 \%$ \\
\hline Informal & 37 & $37,75 \%$ \\
\hline Autônomo & 7 & $7,14 \%$ \\
\hline Outros & 14 & $14,29 \%$ \\
\hline Total & 98 & $100 \%$ \\
\hline
\end{tabular}

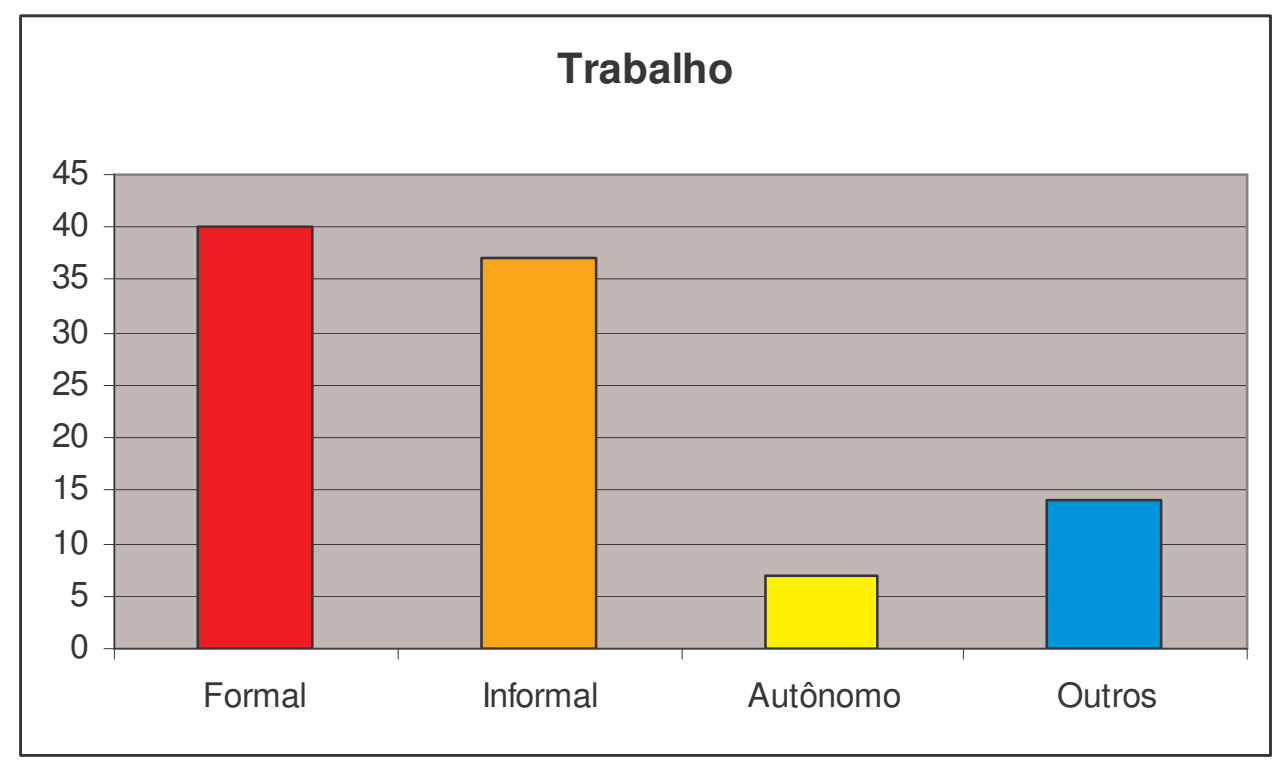


Fonte: dados obtidos através dos questionários.

Referente à moradia, 79 alunos $(80,61 \%)$ moram em casa própria; 10 alunos $(10,2 \%)$ moram em casa alugada; 8 alunos $(8,17 \%)$ em casa cedida e $1(1,02 \%)$ em outro. Esses dados estão dispostos no quadro e gráfico abaixo.

Quadro e gráfico 8: Casa

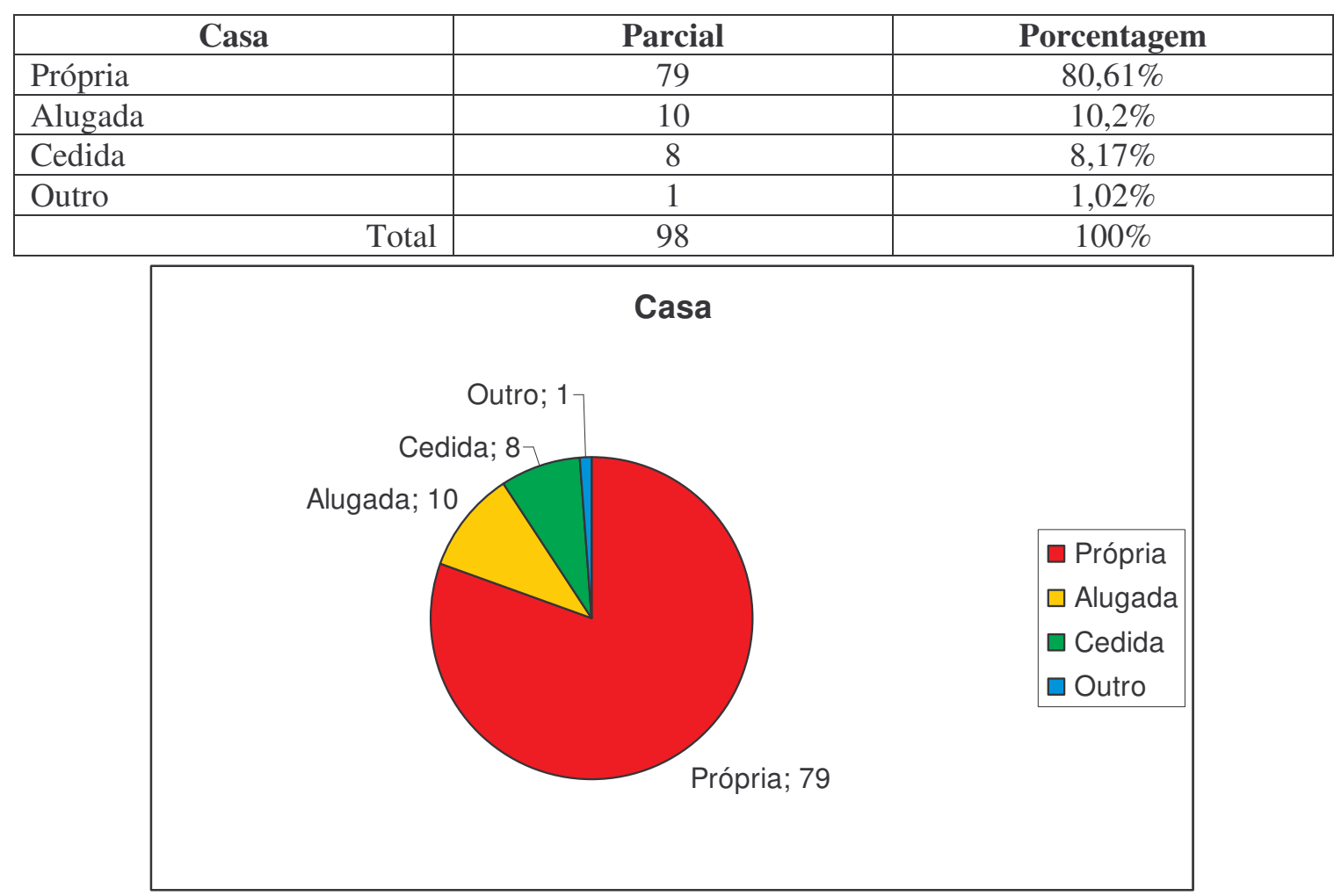

Fonte: dados obtidos através dos questionários.

Considerando a construção da casa, 63 alunos $(64,28 \%)$ possuem casa de alvenaria, seguidos de 27 alunos $(27,55, \%)$ de madeira. Em número de 8 alunos $(8,17 \%)$ a construção da casa é mista.

Quadro e gráfico 9: Casa

\begin{tabular}{|l|c|c|}
\hline \multicolumn{1}{|c|}{ Casa } & Parcial & Porcentagem \\
\hline Material & 63 & $64,28 \%$ \\
\hline Madeira & 27 & $27,55 \%$ \\
\hline Mista & 8 & $8,17 \%$ \\
\hline Outro & 0 & $0,0 \%$ \\
\hline \multicolumn{2}{r|}{} \\
\hline
\end{tabular}




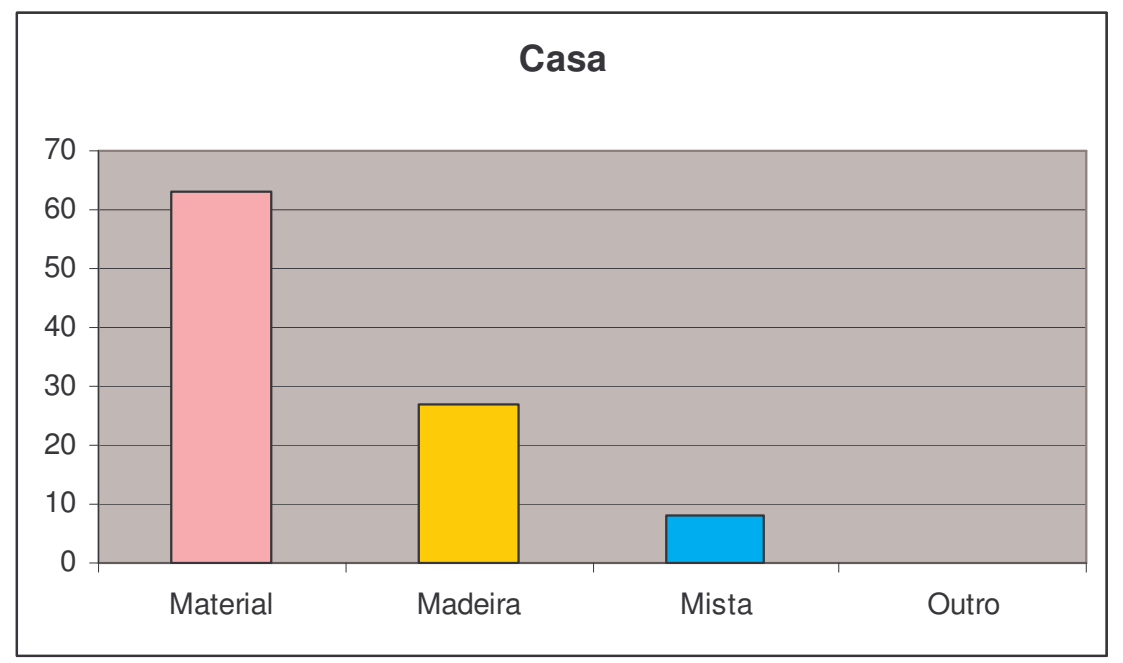

Fonte: dados obtidos através dos questionários.

Com relação ao número de pessoas que moram na casa com o aluno, 29 alunos $(29,59 \%)$ moram com 4 pessoas, 17 alunos $(17,35 \%)$ moram ou com 5 pessoas ou com mais de 5 pessoas. Em seguida 14 alunos $(14,28 \%)$ e 13 alunos (13,27\%) moram com 3 e com 2 pessoas respectivamente. Apenas 2 alunos indicaram que moram sozinhos, conforme quadro e gráfico abaixo.

Quadro e gráfico 10: Quantidade de pessoas que moram na casa

\begin{tabular}{|c|c|c|}
\hline Pessoas & Parcial & Porcentagem \\
\hline 1 pessoa & 6 & $6,12 \%$ \\
\hline 2 pessoas & 13 & $13,27 \%$ \\
\hline 3 pessoas & 14 & $14,28 \%$ \\
\hline 4 pessoas & 29 & $29,59 \%$ \\
\hline 5 pessoas & 17 & $17,35 \%$ \\
\hline Mais de 5 pessoas & 17 & $17,35 \%$ \\
\hline Nenhuma & 2 & $2,04 \%$ \\
\hline Total & 98 & $100 \%$ \\
\hline
\end{tabular}

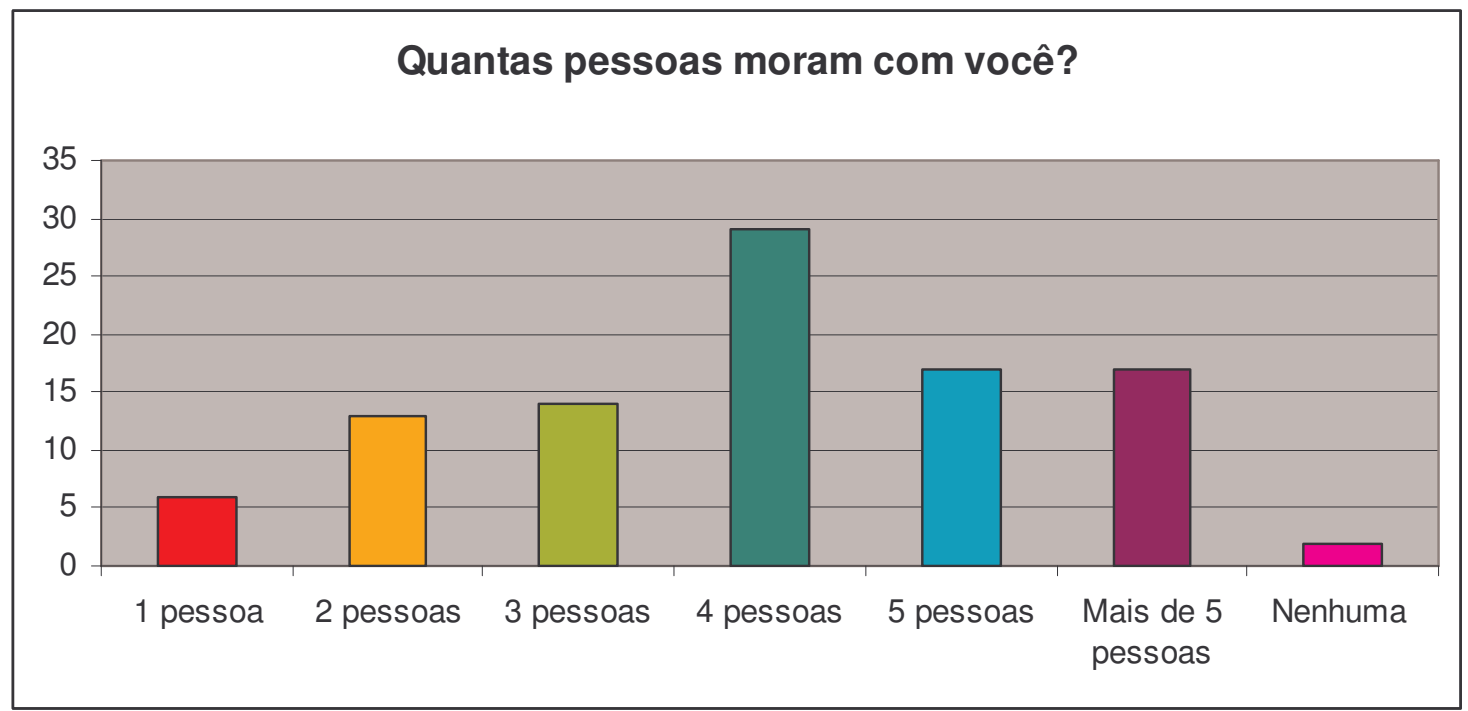

Fonte: dados obtidos através dos questionários. 
Os alunos que participaram da pesquisa, 36 alunos (36,73\%) e 34 alunos $(34,69 \%)$ possuem uma renda de 1 a 2 salários mínimos e até 1 salário mínimo respectivamente. Em número de 17 alunos (17,35\%) possuem uma renda de 2 a 3 salários mínimos, 8 alunos $(8,17 \%)$ recebem de 3 a 4 salários mínimos e apenas 3 alunos $(3,06 \%)$ recebem mais de 4 salários mínimo, conforme demonstra o quadro e gráfico abaixo.

\section{Quadro e gráfico 11: Renda familiar média}

\begin{tabular}{|c|c|c|}
\hline Renda & Parcial & Porcentagem \\
\hline Até 1 salário mínimo (SM) - R \$ 415,00 & 34 & $34,69 \%$ \\
\hline De 1 a $2 S M-R \$ 416,00-R \$ 830,00$ & 36 & $36,73 \%$ \\
\hline De 2 a 3 SM - R\$ 831,00 - R\$ 1245,00 & 17 & $17,35 \%$ \\
\hline De 3 a 4 SM - R\$ 1246,00 - R\$ 1660,00 & 8 & $8,17 \%$ \\
\hline Mais de 4 SM - acima de R $\$ 1660,00$ & 3 & $3,06 \%$ \\
\hline Total & 98 & $100 \%$ \\
\hline
\end{tabular}

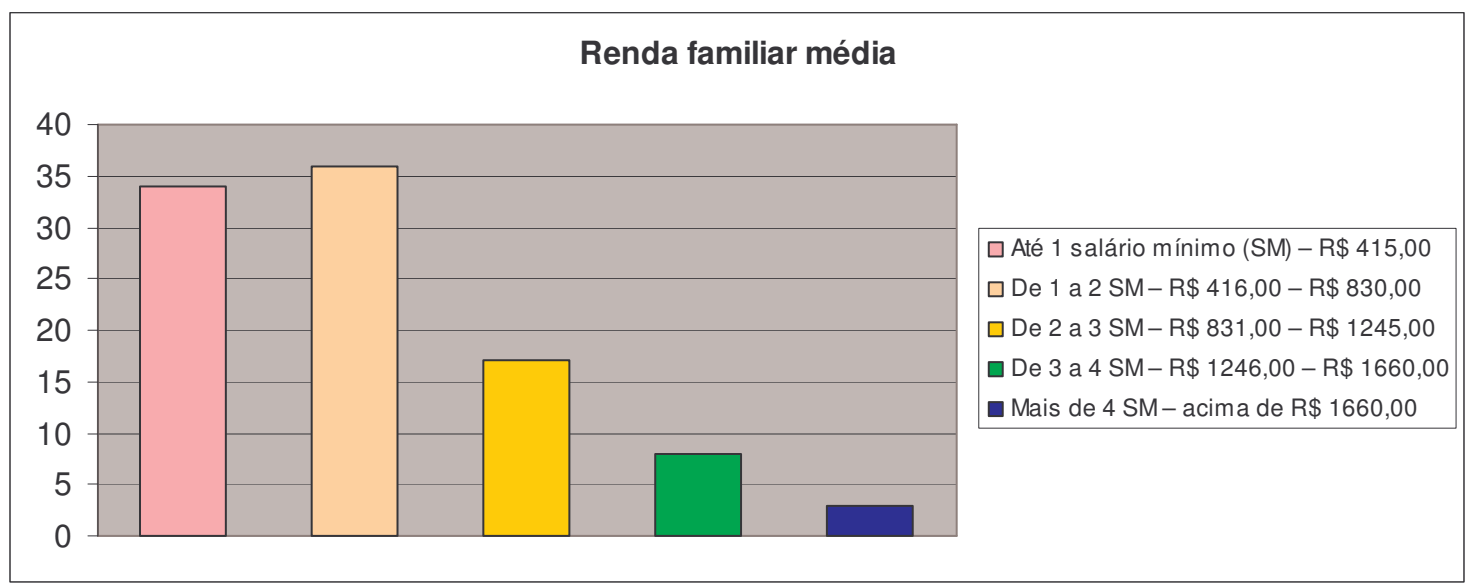

Fonte: dados obtidos através dos questionários.

Considerando questões sobre a escolaridade, 69 alunos $(70,41 \%)$ já haviam freqüentado alguma escola antes da EJA, os demais, 29 alunos (29,59\%), nunca freqüentaram a escola anteriormente. Estes dados podem ser visualizados no quadro e gráfico abaixo.

Quadro e gráfico 12: Freqüentou alguma escola antes da EJA

\begin{tabular}{|c|c|c|}
\hline Já frequientou escola? & Parcial & Porcentagem \\
\hline Não & 29 & $29,59 \%$ \\
\hline Sim & 69 & $70,41 \%$ \\
\hline Total & 98 & $100 \%$ \\
\hline
\end{tabular}




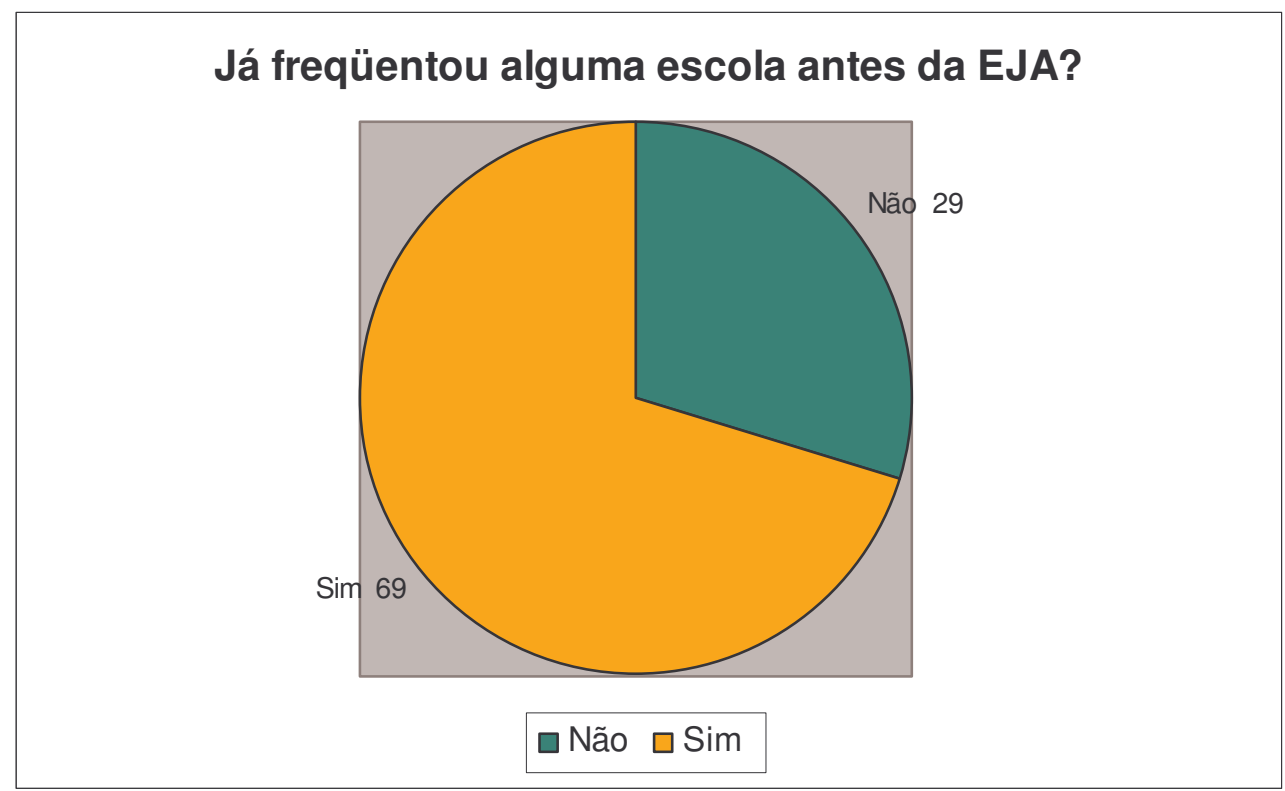

Fonte: dados obtidos através dos questionários.

Quando os alunos foram questionados sobre quanto tempo que estão afastados da escola, mais da metade deles, 47 alunos $(47,96 \%)$ não freqüentam a escola há mais de 5 anos, seguido de 13 alunos $(13,27 \%)$ há 1 ano e 12 alunos $(12,25 \%)$ há mais de 5 alunos. Em número de 9 alunos $(9,18 \%)$ nunca freqüentaram uma escola. Cinco alunos $(5,1 \%)$ registraram a distância da escola, há 23 e 4 anos. E apenas 2 alunos (2,04\%) nunca saíram da escola. Esses dados podem estão explicitados no quadro e gráfico a seguir.

\section{Quadro e gráfico 13: Quando foi que freqüentou a escola pela última vez?}

\begin{tabular}{|c|c|c|}
\hline Quando freqüientou? & Parcial & Porcentagem \\
\hline Há 1 ano & 13 & $13,27 \%$ \\
\hline Há 2 anos & 5 & $5,1 \%$ \\
\hline Há 3 anos & 5 & $5,1 \%$ \\
\hline Há 4 anos & 5 & $5,1 \%$ \\
\hline Há 5 anos & 12 & $12,25 \%$ \\
\hline Mais de 5 anos & 47 & $47,96 \%$ \\
\hline Nunca saiu da escola & 2 & $2,04 \%$ \\
\hline Nunca freqüentou & 9 & $9,18 \%$ \\
\hline Total & 98 & $100 \%$ \\
\hline
\end{tabular}




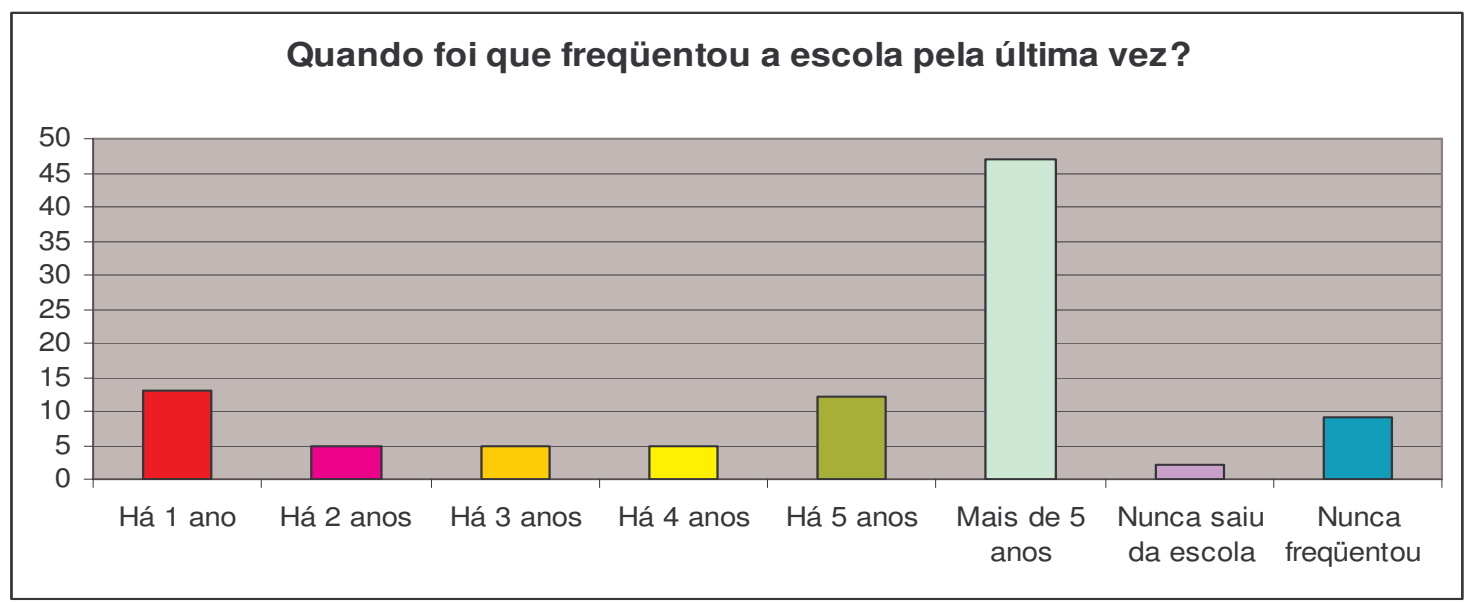

Fonte: dados obtidos através dos questionários.

Considerando que um número expressivo de alunos da pesquisa mostraram interesse pelo estudo e por freqüentar a escola, 89 alunos $(86,73 \%)$ pretendem continuar estudando depois de concluírem a EJA, enquanto 13 alunos $(13,27 \%)$ não pretendem mais estudar.

No que se refere ao que desejam estudar as respostas também variaram sendo que a grande maioria, 40 alunos (40,82\%) não especificaram, entre, o que está representado no quadro e gráfico a seguir.

Quadro e gráfico 14: Após conclusão da EJA, deseja continuar estudando?

\begin{tabular}{|c|c|c|}
\hline $\begin{array}{c}\text { Deseja continuar } \\
\text { estudando? }\end{array}$ & Parcial & Porcentagem \\
\hline - & 13 & $13,27 \%$ \\
\hline Sim & 89 & $86,73 \%$ \\
\hline Total & 98 & $100 \%$ \\
\hline
\end{tabular}

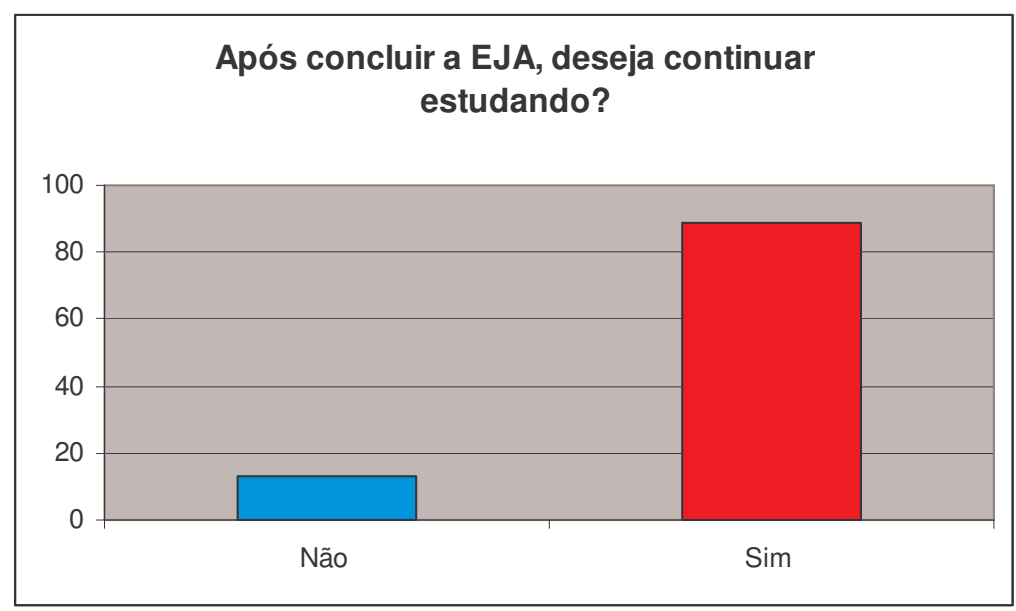

Fonte: dados obtidos através dos questionários.

Sobre este mesmo questionamento, os alunos que responderam que desejam continuar estudando, foram questionados sobre o que desejam estudar. Destes alunos, 27 $(27,55 \%)$ não especificaram, 15 alunos $(15,3 \%)$ pretendem terminar o Ensino Médio, 11 alunos desejam ir para o Ensino Superior, 6 alunos $(6,12 \%)$ querem concluir a $8^{\mathrm{a}}$ série, 5 $(5,1 \%)$ alunos expressaram o desejo de continuar estudando a vida toda, 4 alunos $(4,08 \%)$ pretendem concluir a $5^{\text {a }}$ série e outros 4 alunos (4,08\%) aspiram fazer um Curso 
Profissionalizante. Os referentes dados podem ser observados no quadro e gráfico da seqüência.

\section{Quadro e gráfico 15: O quê?}

\begin{tabular}{|l|c|c|}
\hline & Parcial & Porcentagem \\
\hline Concluir $5^{\text {a }}$ série & 4 & $4,08 \%$ \\
\hline Concluir $8^{\text {a }}$ série & 6 & $6,12 \%$ \\
\hline Curso profissionalizante & 4 & $4,08 \%$ \\
\hline Curso Superior & 11 & $11,22 \%$ \\
\hline Estudar a vida toda & 5 & $5,1 \%$ \\
\hline Não especificou & 27 & $27,55 \%$ \\
\hline Terminar Ensino Médio & 15 & $15,3 \%$ \\
\hline
\end{tabular}

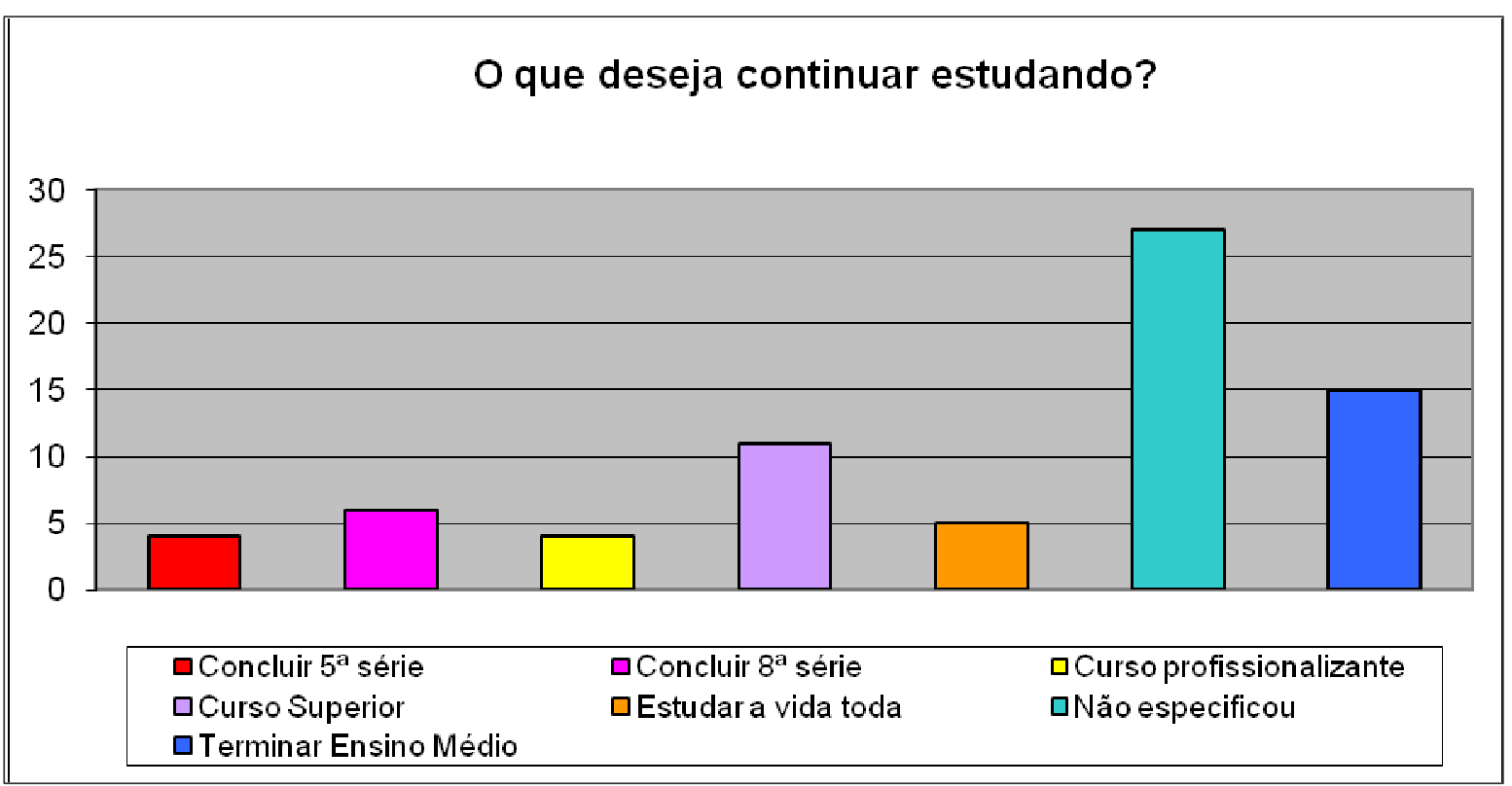

Fonte: dados obtidos através dos questionários.

A evasão escolar ocorre por diferentes motivos, muitas crianças e jovens são submetidos à necessidade de abandonar a escola. Para Ávila (1992), a evasão escolar é,

(...) o abandono da escola antes do término de um curso. Vários fatores contribuem para isso, avultando entre outros, o pauperismo, como o mais ponderável. No ensino de $1^{\circ}$ grau, a evasão escolar é mais acentuada a partir da $3^{\mathrm{a}}$ série, pois que as crianças do meio econômico precário, tendo atingido uma idade em que os pais as consideram capazes de os ajudar, passam a prestar pequenos serviços no lar ou fora do lar, contribuindo muitas vezes financeiramente para o sustento da família (p. 273).

Desta maneira, a evasão torna-se uma questão social que precisa ser discutida, para que a criança permaneça na escola no período adequado. Pois, os resultados da evasão escolar são o elevado número de jovens e adultos que estão retornando a escola, após um longo período para concluírem seus estudos.

Sendo assim, as discussões acerca da evasão pressupõem diversos motivos que levam aos alunos abandonarem a escola. Dentre os participantes da pesquisa, 34 (34,69\%) alunos foram forçados a parar seus estudos por causa do trabalho, 16 (16,33\%) não quiseram responder, $11(11,22 \%)$ deixaram a escola por problemas financeiros, $9(9,18 \%)$ alunos saíram da escola por motivos pessoais, $8(8,16 \%)$ alunos abandonaram a escola por 
problemas familiares, entre as demais causas, foram citadas: ausência de escola ( 2 alunos $2,04 \%$ ), brigas escolares ( 1 aluno - 1,02\%), distância da escola ( 3 alunos $-3,06 \%$ ), filhos (6 alunos $-6,12 \%)$, idade superior a 14 anos ( 2 alunos $-2,04 \%)$, mudanças de localidade (5 alunos $-5,1 \%)$, nunca foi a escola ( 2 alunos $-2,04 \%$ ) e obrigado a estudar a noite (1 aluno - 1,02\%). Estes dados estão dispostos no quadro e gráfico abaixo.

\section{Quadro 18: Motivo para parar os estudos no ensino regular}

\begin{tabular}{|l|c|c|}
\hline & Parcial & Porcentagem \\
\hline Ausência de escola & 2 & $2,04 \%$ \\
\hline Brigas escolares & 1 & $1,02 \%$ \\
\hline Distância da escola & 3 & $3,06 \%$ \\
\hline Filhos & 6 & $6,12 \%$ \\
\hline Idade superior a 14 anos & 2 & $2,04 \%$ \\
\hline Motivos pessoais & 9 & $9,18 \%$ \\
\hline Mudanças de localidade & 5 & $5,1 \%$ \\
\hline Não respondeu & 16 & $16,33 \%$ \\
\hline Nunca foi a escola & 2 & $2,04 \%$ \\
\hline Obrigado a estudar a noite & 1 & $1,02 \%$ \\
\hline Problemas familiares & 8 & $8,16 \%$ \\
\hline Problemas financeiros & 11 & $11,22 \%$ \\
\hline Trabalho & 34 & $34,69 \%$ \\
\hline
\end{tabular}

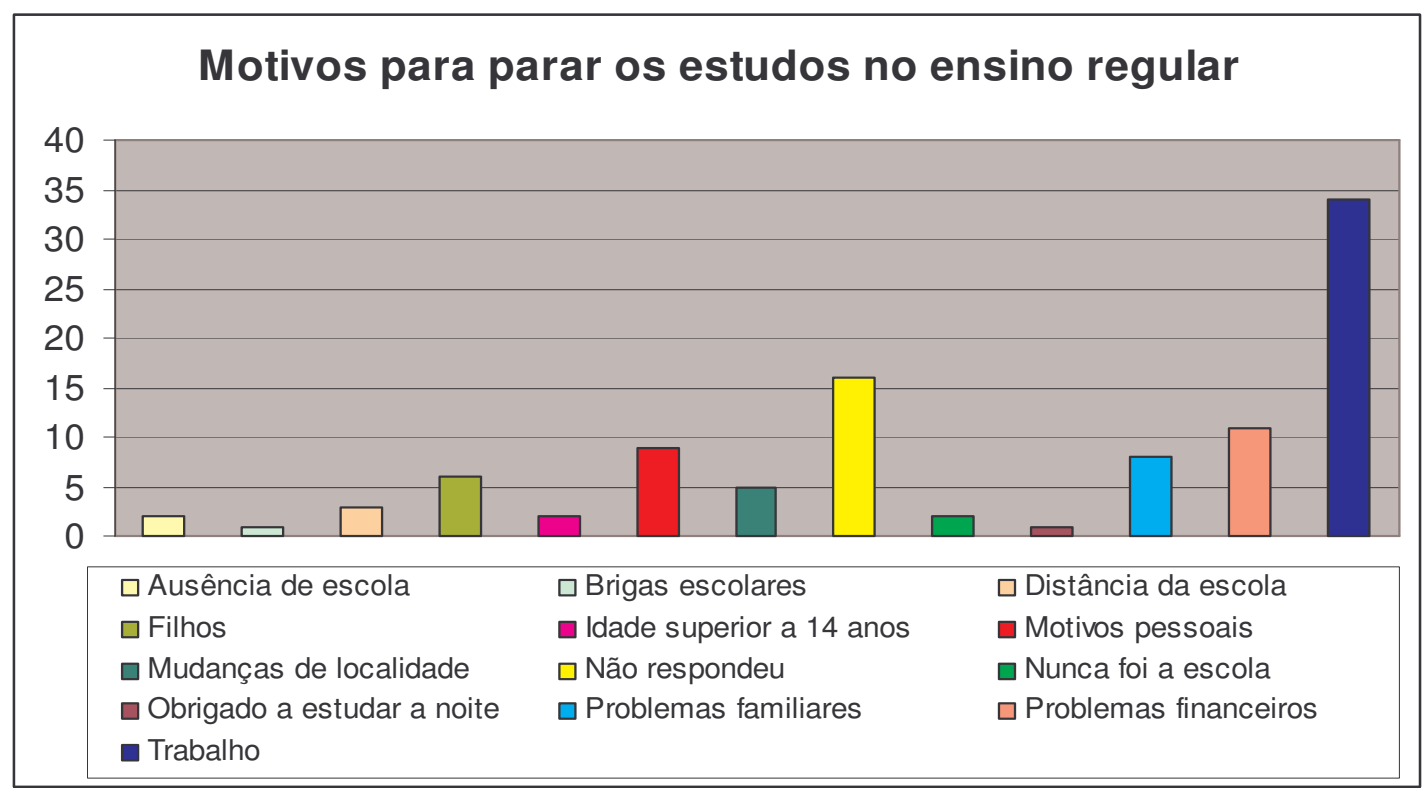

Fonte: dados obtidos através dos questionários.

A evasão escolar apresenta-se por vários motivos, porém muitos alunos retornam a escola para concluírem seus estudos. Entre os motivos que trouxeram os alunos da pesquisa a estudar na EJA, destaca-se a busca de um emprego melhor para 39 alunos $(39,79 \%)$, seguidos de 26 alunos (26,53\%) em busca de mais conhecimentos, $16(16,33 \%)$ alunos retornaram por motivos pessoais, 9 alunos $(9,18 \%)$ voltaram para concluir seus estudos, 8 alunos $(8,16 \%)$ querem se alfabetizar, 5 alunos $(5,1 \%)$ desejam auxiliar os filhos nas tarefas escolares e 4 alunos $(4,08 \%)$ não responderam. Os presentes dados estão no quadro e gráfico da seqüência. 
Quadro e gráfico 19: Motivos para estudar na EJA

\begin{tabular}{|l|c|c|}
\hline & Parcial & Porcentagem \\
\hline Auxiliar os filhos (tarefas) & 5 & $5,1 \%$ \\
\hline Buscar mais conhecimentos & 26 & $26,53 \%$ \\
\hline Concluir os estudos & 9 & $9,18 \%$ \\
\hline Emprego melhor & 39 & $39,79 \%$ \\
\hline Motivos pessoais & 16 & $16,33 \%$ \\
\hline Não Respondeu & 4 & $4,08 \%$ \\
\hline Querer se alfabetizar & 8 & $8,16 \%$ \\
\hline
\end{tabular}

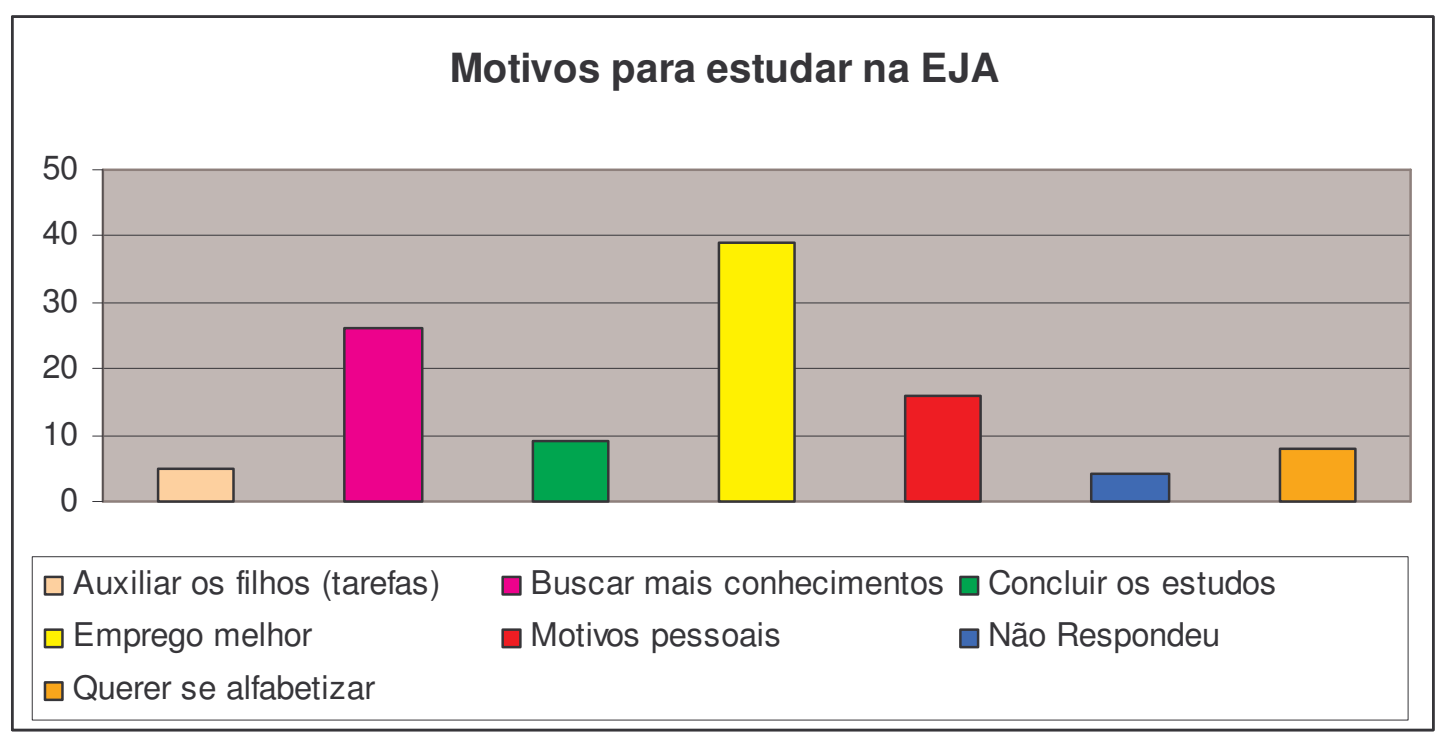

Fonte: dados obtidos através dos questionários.

Referente ao tempo que os alunos estudam em casa, 57 alunos $(58,16 \%)$ não possuem um horário definido, 23 alunos $(23,47 \%)$ estudam após a escola, 13 alunos $(13,27 \%)$ antes da aula, 2 alunos $(2,04 \%)$ no final de semana, outros 2 alunos $(2,04 \%)$ durante a tarde e 1 aluno $(1,02 \%)$ estuda durante as refeições. Os dados apresentam-se no quadro e gráfico abaixo.

Quadro e gráfico 21: Nível escolar quando iniciou o EJA

\begin{tabular}{|c|c|c|}
\hline & Parcial & Porcentagem \\
\hline Não alfabetizado & 18 & $18,37 \%$ \\
\hline Ensino Fundamental & 76 & $77,55 \%$ \\
\hline Ensino Médio & 4 & $4,08 \%$ \\
\hline Total & 98 & $100 \%$ \\
\hline
\end{tabular}




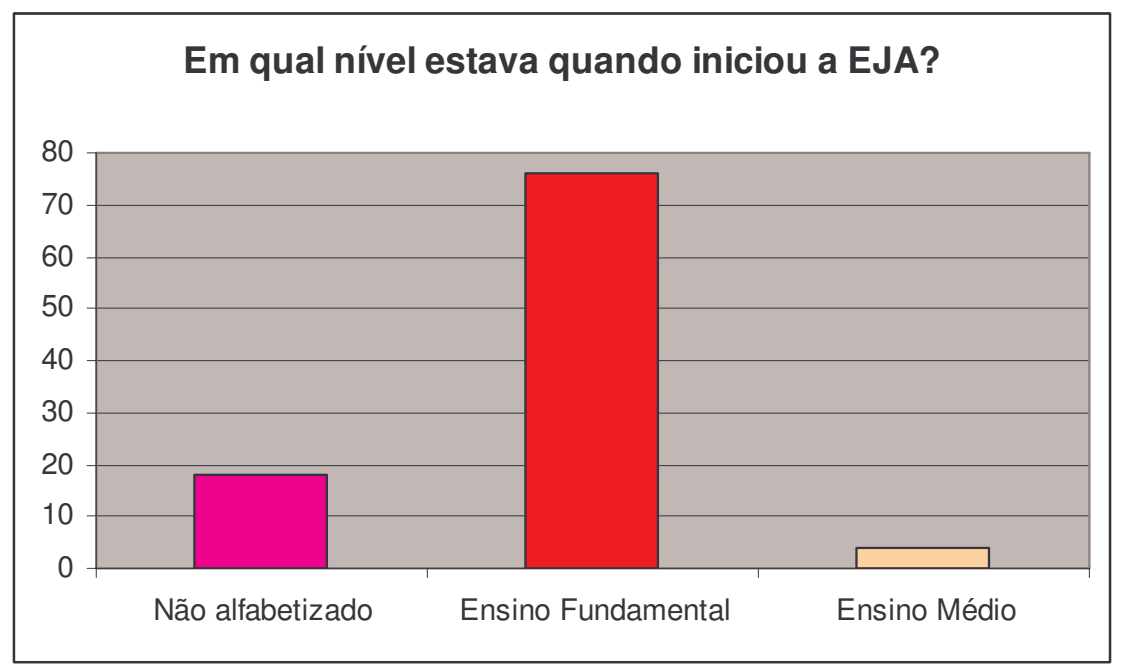

Fonte: dados obtidos através dos questionários.

Em relação ao nível em que os alunos se encontram atualmente, conforme quadro e gráfico a seguir, 89 alunos $(90,82 \%)$ estão no Ensino Fundamental e 9 alunos $(9,18 \%)$ estão no Ensino Médio.

Quadro e gráfico 22: Nível em que o aluno está atualmente

\begin{tabular}{|c|c|c|}
\hline 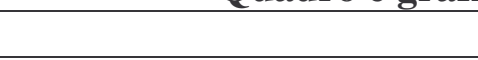 & Parcial & Porcentagem \\
\hline Ensino Fundamental & 89 & $90,82 \%$ \\
\hline Ensino Médio & 9 & $9,18 \%$ \\
\hline Total & 98 & $100 \%$ \\
\hline
\end{tabular}

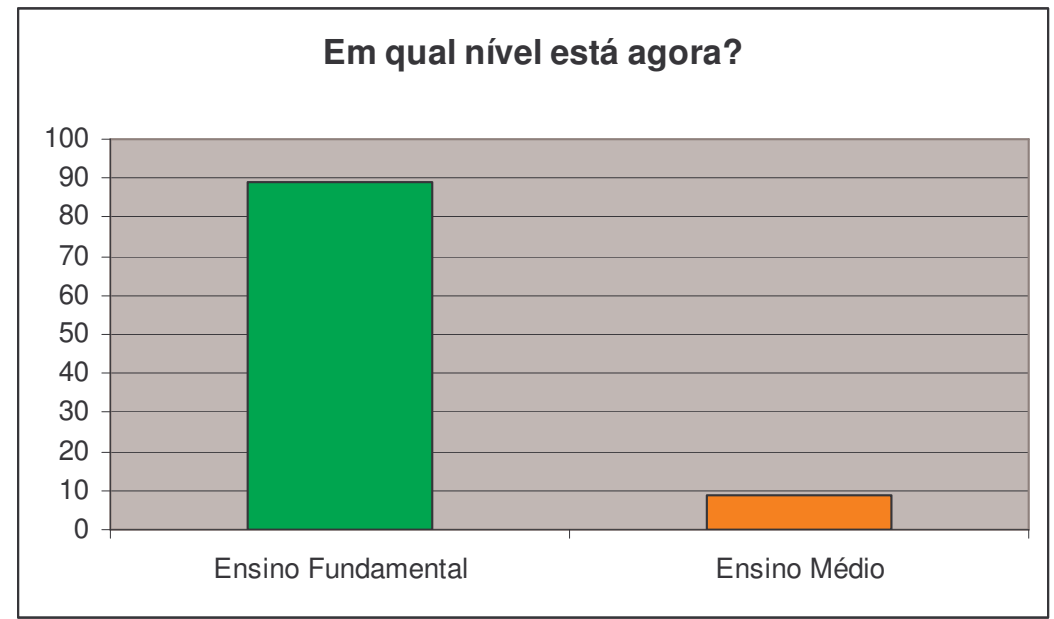

Fonte: dados obtidos através dos questionários.

Os alunos também foram questionados sobre os meios nos quais geralmente procuram noticias, uma vez que há a necessidade de estarem informados para poder haver comparação entre o que estão aprendendo e o que está acontecendo na sociedade. Assim, 75 alunos $(76,53 \%)$ encontram na televisão o meio para estar atualizado e buscar noticias, 40 alunos $(40,81 \%)$ buscam notícias no rádio, 12 alunos $(12,24 \%)$ lêem jornal, 8 alunos $(8,17 \%)$ utilizam a internet, 1 aluno $(1,02 \%)$ busca em conversas informais e outro aluno $(1,02 \%)$ não especificou. Os dados estão dispostos no quadro e gráfico a seguir. 
Quadro e gráfico 23: Meios de informações para buscar notícias

\begin{tabular}{|l|c|c|}
\hline & Parcial & Porcentagem \\
\hline Jornal escrito & 12 & $12,24 \%$ \\
\hline Televisão & 75 & $76,53 \%$ \\
\hline Rádio & 40 & $40,81 \%$ \\
\hline Internet & 8 & $8,17 \%$ \\
\hline Conversas informais & 1 & $1,02 \%$ \\
\hline Outros & 1 & $1,02 \%$ \\
\hline
\end{tabular}

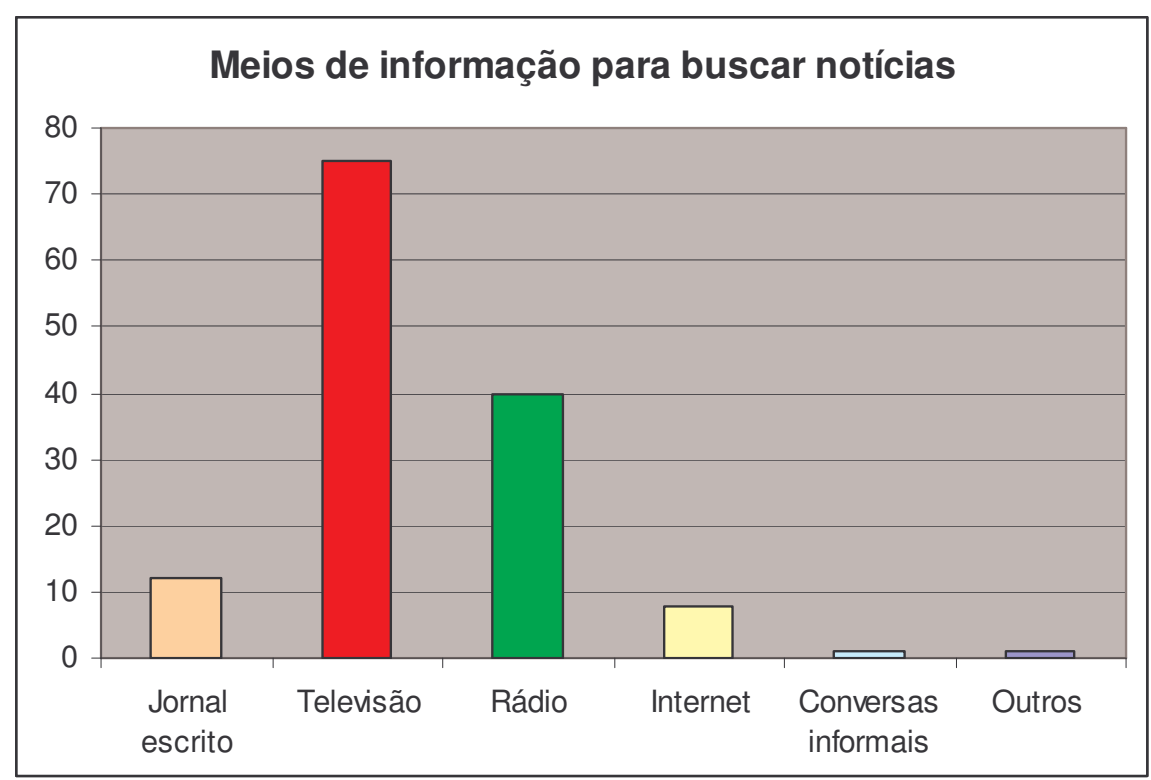

Fonte: dados obtidos através dos questionários.

\section{CONSIDERAÇÕES FINAIS}

A EJA sempre foi considerada como uma educação compensatória e de segunda categoria, entretanto percebeu-se que os alunos atribuem à educação grande valor e principalmente no que se refere a possibilidade que ela oferece para uma maior inserção social e maior ascensão profissional, contribuindo também para a superação desta visão distorcida e reducionista da EJA.

$\mathrm{Na}$ cidade de Ponta Grossa, a EJA vem apresentando nos últimos anos um crescimento significativo em número de alunos. Todavia, ainda são necessárias Políticas Públicas especificas que atendam essa modalidade de ensino, propiciando uma educação de qualidade para jovens, adultos e idosos que não tiveram acesso de freqüentar a escola no período regular.

Também, faz-se necessário uma política nos âmbitos Federal, Estadual e Municipal, que viabilize recursos para que seja realizado um trabalho de melhor qualidade. O estudo, a pesquisa e a produção de material didático-pedagógico são importantes para a realização desse trabalho.

Superar todo esse contexto no qual se construiu a Educação de Jovens e Adultos que se apresenta hoje não é fácil. É preciso, antes de tudo, entender a escolarização desses alunos como de fundamental importância, pois eles são os pais, as mães, os trabalhadores, 
aqueles que constroem, com seu trabalho, os meios necessários à sobrevivência e que na história deixam a sua contribuição.

A superação do quadro crônico de analfabetos ou semi-analfabetos em nosso país está a exigir o repensar desta importante questão recorrente no processo de nosso desenvolvimento histórico, sendo necessário promover debates acadêmicos, elaboração de pesquisas e propostas que visem superar a situação de extrema desigualdade social e educacional vigentes no contexto brasileiro.

Di Pierro, Jóia e Ribeiro (2001) consideram que os governos precisam assumir mais claramente uma atitude convocatória, chamando toda a sociedade a engajar-se em iniciativas voltadas a elevação do nível educativo da população. $\mathrm{O}$ teor desse chamado deve contemplar, especialmente, a motivação para que todos continuem aprendendo ao longo da vida, visto que a necessidade, a vontade e a possibilidade de aprender são inerentes a todos os seres humanos, do nascimento à velhice. É preciso, portanto, considerar também, a necessidade de qualificar a demanda por esses serviços, por meio de ações culturais e políticas voltadas ao amplo reconhecimento do valor da educação continuada como estratégia de promoção de eqüidade educativa e social.

Percebe-se, portanto, que a Educação de Jovens e Adultos, apresenta-se como questão ampla e complexa, que não será resolvida apenas em nível de decisões governamentais, mas, exige o engajamento de todas as pessoas que acreditam no potencial humanizador e transformador da educação, oportunizando a inserção crítica e participativa de seus usuários nos destinos da sociedade.

\section{REFERÊNCIAS}

ÁVILA, F. B. Pequena enciclopédia de moral e civismo. Brasília: MEC, 1992.

ARROYO, M. G. Educação de jovens-adultos: um campo de direitos e de responsabilidade pública. In: SOARES, L., GIOVANETTI, M. A., GOMES, N. L. (org). Diálogos na educação de jovens e adultos. Belo Horizonte: Autêntica, 2006.

BRASIL. Constituição Federal. Brasília, 1998.

Censo escolar. Brasília: MEC/INEP, 2008.

Diretrizes Curriculares Nacionais para a Educação de Jovens e Adultos. Brasília: MEC, 2000. 1996.

Lei de Diretrizes e Bases da Educação Nacional. Lei 9394/96. Brasília: MEC,

COELHO, A. M. S; EITERER, C.L. A didática na EJA. In: SOARES, L; GIOVANETTI, M. A; GOMES, N. L. Diálogos na Educação de Jovens e Adultos. Belo Horizonte: Autêntica, 2006, p. 169-183.

DI PERRO, M.C., JÓIA, O., RIBEIRO, V. M. Visões da Educação de Jovens e Adultos no Brasil. Disponível em: http:/www.scielo.br/pdf/ccedes. Acesso em 20/11/2005.

FREIRE, P. Educação e mudança. São Paulo: Paz e Terra, 30ª ed., 2002. 
Pedagogia do oprimido. São Paulo: Paz e Terra, 45 ed., 2005.

FURTER, P. Educação e vida. Rio de Janeiro: Vozes, 1976.

GADOTTI, M; ROMÃO J. E. Educação de Jovens e adultos: teoria, prática e proposta. 2 ed. São Paulo: Cortez, 2005.

INAF. Indicador de analfabetismo funcional. São Paulo: Instituto Paulo Montenegro/IBOPE, 2007.

PICONEZ, S. C. B. Educação escolar de jovens e adultos. Campinas: Papirus, 2002.

PINTO, A. V. Sete lições sobre a educação de adultos. São Paulo, Cortez, 6a ed. 1989.

PORTO, Y. S. Educação de jovens e adultos: o desafio de ressignificá-la. In: FARENZENA, R. C. (org). Educação de Jovens e Adultos: movimento políticopedagógico. Passo Fundo: UPF, 2004.

QUEIROZ, L. D. Um estudo sobre a evasão escolar: para se pensar na inclusão escola. 2004. Disponível em: <www.anped.org.br>. Acesso em: 18 nov. 2008.

SANTOS, M. L. L. Educação de jovens e adultos: marcas da violência na produção poética. Passo Fundo: UPF, 2003.

SAVIANI, D. Pedagogia histórico-crítica. $8^{\text {a }}$ ed. Campinas: Autores Associados, 2003.

TEODORO, A. Globalização e educação: políticas educacionais e novos modos de governação. São Paulo: Cortez, 2003.

VIEIRA, S. L. Política (s) e gestão da educação básica: revisitando conceitos simples. In: Revista brasileira de política e administração da educação. V.23, n.1, p. 56-69, jan/abr, 2007.

\footnotetext{
${ }^{\mathrm{i}}$ Universidade Estadual de Ponta Grossa. Doutora em Filosofia e Ciências da Educação. Professora Associada do Departamento de Educação e Professora Permanente do Mestrado em Educação. Email:

ii Universidade Estadual de Ponta Grossa. Mestranda em Educação, bolsista Capes.

iii Faculdade União. Mestre em Ciências Sociais Aplicadas. Coordenadora e Professora do Curso de Direito.
}

Artigo recebido em: 30/6/2009

Aprovado para publicação em 31/08/09 